\title{
INTEGRATING CINEMA: UNCOVERING THE FILM LIBRARIANSHIP OF WILLIAM J. SLOAN AT THE NEW YORK PUBLIC LIBRARY
}

by

Isaac Prusky

Bachelor of Fine Arts, University of Lethbridge, Lethbridge, Alberta, 2014

\author{
A thesis \\ presented to Ryerson University \\ in partial fulfillment of the \\ requirements for the degree of \\ Master of Arts \\ in the program of
}

Film and Photography Preservation and Collections Management

Toronto, Ontario, Canada, 2018

New York City, New York, United States, 2018

(C) Isaac Prusky 2018 


\section{Author's Declaration for Electronic Submission of Thesis}

I hereby declare that I am the sole author of this thesis. This is a true copy of the thesis, including any required final revisions, as accepted by my examiners.

I authorize Ryerson University to lend this thesis to other institutions or individuals for the purpose of scholarly research.

I further authorize Ryerson University to reproduce this thesis by photocopying or by other means, in total or in part, at the request of other institutions or individuals for the purpose of scholarly research.

I understand that my thesis may be electronically available to the public. 


\author{
$\underline{\text { Abstract }}$ \\ Integrating Cinema: Uncovering the Film Librarianship of William J. Sloan at the New York \\ Public Library \\ Master of Arts, 2018 \\ Isaac Prusky \\ Film and Photography Preservation and Collections Management \\ Ryerson University
}

This thesis explores the career of William J. Sloan, the first Supervising Film Librarian for The New York Public Library, who worked at the institution from 1958 to 1980. The objective is to demonstrate how Sloan ensured The New York Public Library remain relevant to future generations through expansion of its moving image media collection and activities. This has been accomplished by examining Sloan's concerted efforts to promote moving image media as a film librarian, educator, and programmer during his time at The New York Public Library, as well as influential media projects he completed there. By showing that Sloan expanded the moving image media collection of The New York Public Library through his work in a number of fields, this thesis highlights Sloan's lasting influence on the Library and New York film community today, as well as his role in establishing the Reserve Film and Video Collection. 


\section{Acknowledgements}

I would like to begin by thanking Dr. Izabella Pruska-Oldenhof for her tremendous support over the course of this project. Your expertise, positivity, patience, and keen eye made all the difference, and I'm extremely grateful. I must enthusiastically thank my supervisor and friend, Elena Rossi-Snook, without whom there would be no thesis at all. You trusted me with the safety of the documents utilized for this thesis, and to tell a story about what makes this collection so incredible and worth fighting for. I'm indebted to you for that. Thank you for encouraging me to go my own way, especially when times got tough. You are a true inspiration. Thank you to everyone on the faculty of the F+PPCM program. You made this opportunity possible and have been nothing but supportive of my work. A very special thank you to my friends and family who were always there for a morale-boost. I could not have done this without you. Lastly, thank you to Jennifer Sloan for trusting the Reserve Film and Video Collection with your father's personal archive. William J. Sloan was both an extraordinary librarian and an extraordinary man. I'm truly honoured that I was given the chance to bring light to his life and accomplishments. 


\section{Table of Contents}

Author's Declaration Statement $\quad$ ii

$\begin{array}{ll}\text { Abstract } & \text { iii }\end{array}$

Acknowledgements $\quad$ iv

$\begin{array}{ll}\text { Introduction } & 1\end{array}$

Chapter 1: A Survey of Literature on William J. Sloan 5

1.1 A Biographical Sketch of William J. Sloan 5

1.2 Sources on William J. Sloan and the Reserve Film and Video Collection 7

$\begin{array}{ll}1.3 \text { Conclusion } & 9\end{array}$

$\begin{array}{ll}\text { Chapter 2: Methods } & 11\end{array}$

2.1 Background 11

2.2. Document Inspection and Categorization $\quad 12$

2.3 Appendices 16

2.4 Methods: Issues and Limitations 16

Chapter 3: William J. Sloan and The New York Public Library Film \& Video Collection 19

3.1 An Alert Librarian $\quad 19$

3.2 Early Years and Influence on the Film Library 22

3.3 Professional Endeavors and Roles 28

3.4 Contributions to American Library Association 30

3.5 Film Library Information Council and Film Library Quarterly 34

3.6 Teaching Career $\quad 37$ 
Chapter 4: Libraries as "Centers for Community Educational and Cultural Activity" $\quad 40$

4.1 Perspectives on Library Film Programming $\quad 40$

4.2 Film Programming, Workshops, and Seminars 40

4.3 "Video Art as a Library Medium” $\quad 46$

4.4 The Teen-Age Video Workshop $\quad 49$

$\begin{array}{ll}\text { Conclusion } & 52\end{array}$

Appendix A: William J. Sloan’s Syllabi 53

Appendix B: Film Programs Organized by William J. Sloan 56

Appendix C: Film Programs Organized by Film Library Information Council (FLIC) 61

Appendix D: Information on Film Programs Organized by William J. Sloan 63

$\begin{array}{ll}\text { Bibliography } & 70\end{array}$ 


\section{Introduction}

William J. Sloan (b. 1927 Regina, Canada - d. 2017 New York, United States), film librarian, educator, and programmer ensured that The New York Public Library remained relevant to future generations through his visionary ideas about the role of libraries in society as public institutions, the necessity of libraries to stay current and keep up with the changing media environment, and for library collections to reflect that environment by including non-print, audiovisual media (film at first and then later video). As the first film librarian at The New York Public Library (1958-1980), Sloan oversaw what is today the Reserve Film and Video Collection (RFVC) at the Donnell Library Center in New York City, a circulating collection of films and videos that can be accessed by the public free of charge. He prioritized the acquisition of independent or non-commercial moving image media, and believed public libraries had a civic duty to collect, circulate, and exhibit non-print material, thereby maintaining currency in present-day and emerging media of communication, while remaining relevant for the public. ${ }^{1}$ Moreover, Sloan's emphasis on public and free of cost access to moving image media set The New York Public Library apart from many comparable film centers, which were predominately frequented by scholars and filmmakers. ${ }^{2}$ The New York Public Library has endured as a centre for moving image media due to Sloan's focused and uncompromising efforts to modernize it through his many activities, some of which included organizing public exhibitions of ground-breaking moving image works from the Library's film and video collection; overhauling and revamping Library Science curricula at institutions he taught at; spearheading film library

\footnotetext{
${ }^{1}$ Non-print material refers to non-book or text materials, i.e., film and videotape. The term "non-print" is used to emphasize Sloan's promotion of film and videotape as educational tools equal to the book (print) collection of The New York Public Library.

${ }^{2}$ Notable examples include The Museum of Modern Art, New York University, Anthology Film Archives, and Library of Congress.
} 
organizations; organizing film and video production workshops for youth; and making sure that the Library's film and video collection always reflected the needs of the community it served.

The objective of this thesis is twofold: first, to present Sloan as a visionary librarian whose commitment to collecting, exhibiting, writing, and educating the public about film and video at The New York Public Library contributed to moving image works being accepted at the institution; and, second, to demonstrate the ways in which Sloan made The New York Public Library a vital and relevant center for moving image media today. I will accomplish this by detailing Sloan's commitment to the social function of public institutions, his values and goals as a film librarian at The New York Public Library, his role in building the RFVC, and how his activities influenced this institution to embrace moving image media, e.g., his publications, teaching at post-secondary institutions, film programming, community outreach, grant proposals for purchasing films and videos, and work with the American Library Association and Film Library Information Council. Exploring these peripheral activities of his library career is imperative to demonstrating his importance within the film community of New York City, and his impact on the RFVC.

This thesis consists of four main chapters, a conclusion, and four appendices containing illustrations and reference material. The first chapter surveys existing literature to provide a biographical sketch of Sloan and the extent of his activities as a film librarian, educator, and programmer in New York City. It also describes the historical context of the RFVC, which he helped develop. The second chapter details the process of inspection used in reviewing nine boxes of Sloan's documents, eight of which were donated to The New York Public Library in 2017 by his daughter, Jennifer Sloan. The third and fourth chapters offer information about Sloan 
that was absent in existing literature, thus providing a more thorough account of the extent of his activities at The New York Public Library: in Chapter 3, within his professional community; and Chapter 4, within local communities in New York City. Both chapters relied on primary sources, i.e., Sloan's documents contained in the aforementioned nine boxes. Many of these documents had not been studied or used prior to this thesis, and were made available to me by the current Collection Manager of the RFVC, Elena Rossi-Snook. Chapter four concludes with a detailed account of Sloan's objective to collect, promote, and circulate tape-based media at The New York Public Library, which was accomplished through two major projects: the Teen-Age Video Workshop, and the Video/Film Study Center. Both projects emphasize the importance of collecting film and video in public libraries, which, for Sloan, was inseparable from the fundamental role of public libraries, i.e., to serve their communities by providing access to knowledge through print and non-print materials in their collections, and by educating communities about the present-day media (how to interpret and use it). Thus, chapters three and four provide concrete evidence for my central argument that Sloan's visionary ideas and activities as film librarian had a lasting influence on The New York Public Library.

These four chapters are followed by a conclusion, which summarizes my findings, outlines how they support the main argument, and identifies limitations of this thesis and, hence, possible areas to explore by future scholars interested in Sloan or The New York Public Library. This thesis also contains four appendices, which consist of a sample of materials accessed during the practical portion of my thesis research and residency at The New York Public Library: the inspection of documents in Sloan's nine boxes. Appendix A contains Sloan's two syllabi for courses he taught at New York University and Pratt Institute respectively. Appendix B contains 
examples of Sloan's film programs; these were presented at venues other than The New York Public Library. Appendix C includes a sample of film programs and symposia organized by the Film Library Information Council, of which Sloan was acting president. The fourth appendix, Appendix D, consists of spreadsheets (compiled by me) that provide details and numerical information about Sloan's film programs dating from 1966 to 1978, e.g., program titles, films screened, dates, venues, attendance numbers, and contextual notes. It is my hope that this reference material, along with my findings and analysis, will establish Sloan as a trailblazer and champion of moving image media at The New York Public Library, whose work and ideas about the function of public libraries in society were key to the enduring relevance of The New York Public Library for this generation and those to come. 


\section{Chapter 1: A Survey of Literature on William J. Sloan}

This chapter surveys secondary sources on Sloan written by archivists, librarians, and scholars, as well as primary sources, e.g, Sloan's personal documents, specifically his curriculum vitae, personal correspondence, and memorandums; and texts by others in newspaper and journal articles, chapters in books, and press releases published during his time at The New York Public Library. An online source was also consulted in order to corroborate dates and background information for the current state of RFVC.

The first part of this chapter details Sloan's life and career prior to joining The New York Public Library, and briefly touches upon what became of the Film Library (RFVC) he oversaw there. ${ }^{3}$ It then proceeds to discuss in more detail the NYPL Film Library and Sloan's role in managing and maintaining it. The concluding section of this chapter emphasizes the importance of primary sources in this research, as these provide a more complete picture of Sloan and his contributions as its film librarian, which existing secondary sources have come short of delivering. As this survey of literature will demonstrate, texts on Sloan are quite limited in number and scope, especially those texts that focus on the period when Sloan worked at The New York Public Library (1958 to 1980); therefore further research on Sloan's career at this public institution is necessary.

\subsection{A Biographical Sketch of William J. Sloan}

William J. Sloan (1927-2017) was born in the Canadian prairies of Regina, Saskatchewan on November 11, 1927. Growing up during the Depression, Sloan saw socialist cooperatives

\footnotetext{
3 "Film Library" will be used hereafter to refer to the RFVC pre-2008.
} 
being formed to aid the poverty stricken community of his region in Western Canada. This early brush with leftist politics would inform his personal and professional values for the rest of his life. $^{4}$

After moving with his family from Saskatchewan to Sackville, New Brunswick, Sloan received his Bachelor of Arts from Mount Allison University in 1949, and later taught high-school English in Ridgeway, Ontario from 1951 to 1953. Unhappy as a high-school teacher in small-town Ontario, he and his wife Gwen (1929-2015) decided to settle in New York City, where he received his Master of Library and Information Science from Columbia University (1954). He was subsequently hired to work in The New York Public Library Picture Collection at the Mid-Manhattan branch on 5th Avenue, where he worked under artist and librarian Romana Javitz. ${ }^{5}$ With Javitz's recommendation, Sloan was promoted to Supervising Film Librarian at the Donnell Library Center on West 53rd Street in 1958. It was here that he helped launch and spearhead the NYPL Film Library. ${ }^{6}$

Under Sloan's leadership, the Film Library evolved from a "collection of adult-education, public-service documentaries," to become a center for independent cinema, film and video production, workshops, and media studies, creating a space for public discussion and serving the greater community of New York. ${ }^{7}$ Sloan oversaw this collection until 1980 when he resigned to develop and manage the circulating film and video collection at the Museum of Modern Art. ${ }^{8}$

\footnotetext{
${ }^{4}$ Jennifer Sloan, “Speaking Notes for Bill Sloan's Memorial," Google doc, October 2017, 1, https://docs.google.com /document/d/1bSIdVO8ss2eEI7rcxE_NLITasNabl1Sh1UsOhgt80-4/edit?ts=5b50caal [Accessed July 21, 2018]

${ }^{5}$ Ibid., 2.

${ }^{6}$ William J. Sloan, Curriculum Vitae, n.d., William J. Sloan Documents, New York Public Library, New York [hereafter cited as Sloan, Curriculum Vitae, Sloan Documents], n.p.

${ }^{7}$ The Museum of Modern Art, "New Film Department Appointments Announced at Museum of Modern Art," The Museum of Modern Art, press release, August 26, 1980, 2.

${ }^{8}$ William J. Sloan, William Sloan to Edwin Holmgren, April 23, 1980, letter, William J. Sloan Documents, New York Public Library, New York, n.p.
} 
Following the closure of the Donnell Library Center in 2008, the film department Sloan lead was renamed the Reserve Film and Video Collection and subsequently moved to the Lincoln Center branch of The New York Public Library, where it remains today. ${ }^{9}$

\subsection{Sources on William J. Sloan and the Reserve Film and Video Collection}

In her article "Continuing Ed: Educational Film Collections in Libraries and Archives," Elena Rossi-Snook confirms that Sloan helped established the Reserve Film and Video Collection, which she currently oversees as its Collection Manager. ${ }^{10}$ Moreover, Rossi-Snook argues that, as its first Film Librarian, Sloan strongly believed that The New York Public Library should collect, circulate, and program films that would expose audiences to new forms of cinematic art and present-day issues of social justice. ${ }^{11}$ Film historians Patricia R. Zimmerman and Scott MacDonald, in their book The Flaherty: Decades in the Cause of the Independent Cinema, concur with Rossi-Snook by identifying Sloan as the architect behind what would become the RFVC, and his reputation as a trailblazing film programmer within New York City. ${ }^{12}$

Furthermore, in her book The Citizen Machine: Governing by Television in 1950s America, film educator Anna McCarthy describes how Sloan's liberal and socially orientated views influenced his work at The New York Public Library, specifically in regard to acquisition of films for the Library's collection that focused on racial conflict and the underprivileged.

\footnotetext{
${ }^{9}$ The New York Public Libary, “Donnell Library Center,” New York Public Library, https://www.nypl.org/about/ locations/donnell [accessed April 14, 2018].

${ }^{10}$ Elena Rossi-Snook, "Continuing Ed: Educational Film Collections in Libraries and Archives," Learning With the Lights Off: Educational Film in the United States, Devin Orergon, Marsha Orergon, and Dan Streible, eds. (Oxford: Oxford University Press, 2012), 490.

${ }^{11}$ Elena Rossi-Snook, "Persistence of Vision: Public Library 16mm Film Collections in America," The Moving Image 5, 1 (2005), 19.

${ }^{12}$ Patricia R. Zimmerman and Scott MacDonald, The Flaherty: Decades in the Cause of Independent Cinema (Bloomington: Indiana University Press, 2017), 56.
} 
McCarthy notes Sloan's keen eye for racial representation and social justice in films during the Civil Rights Movement, such as the 1956 documentary A City Decides (Charles Guggenheim), which he perceived as too focused on white viewers to be considered an effective educational tool for library patrons. ${ }^{13}$

The editor of the Managing Performing Arts Collections in Academic and Public Libraries reference guide, librarian Carolyn A. Sheehy argues that the popularization of independent film in the 1960 s and 1970s led to the creation of cinema studies programs, which resulted in the proliferation of film library collections. Sheehy maintains that independent cinema of this era revitalized and widened the scope of what public libraries could collect, noting the attention Sloan brought to such films through his work as chairman of the American Library Association Motion Picture Preview Subcommittee. ${ }^{14}$ As chairman of this subcommittee, Sloan published reviews of independent or non-commercial documentary and experimental films, which he sought to collect and program at The New York Public Library throughout the 1960s and 1970s.

In his book Lost Illusions: American Cinema in the Shadow of Watergate and Vietnam 1970-1979, film educator and scholar David A. Cook discusses Sloan's film programming career during the 1970s. Cook maintains that Sloan was known for regularly including documentaries in film programs at the Donnell Library Center in New York City, and for editing Film Library Quarterly, a journal published by the Film Library Information Council, which featured articles

\footnotetext{
${ }^{13}$ Anna McCarthy, The Citizen Machine: Governing By Television in 1950s America (New York: New York University Press, 2010), 100-101.

${ }^{14}$ Carolyn A. Sheehy, ed., Managing Performing Arts Collections in Academic and Public Libraries (Westport: Greenwood Press, 1994), 10-11.
} 
on changing trends in moving image media and film librarianship. ${ }^{15}$ Sloan's work with this publication from 1967 to 1984 is a key factor in his commitment to integrating moving image media at The New York Public Library, particularly as carrier and playback technology progressed over the course of the 1970 s. $^{16}$

Lastly, UCLA Film and Television Archive director Jan-Christopher Horak's article "Archiving, Preserving, Screening 16mm" indicates that the Reserve Film and Video Collection continues to fulfill Sloan's vision of an inclusive and diverse library of moving image media. Moreover, Horak asserts that in 2006, the Donnell Library Center still actively acquired, purchased, and replaced $16 \mathrm{~mm}$ prints of independent or non-commercial films for the public to access; a practice that continues under Elena Rossi-Snook at The New York Public Library for the Performing Arts today. ${ }^{17}$

\subsection{Conclusion}

This survey of literature provides a glimpse into what others have written about Sloan and his work at the New York Public Library over the past twenty-five years. As this chapter demonstrates, secondary literature does not provide a full picture of how Sloan promoted moving image media at The New York Public Library. Articles by Rossi-Snook, Zimmerman, and MacDonald confirm Sloan's influence as a film librarian and programmer, but do not touch upon specific programs, workshops, or video projects he spearheaded at The New York Public Library. Likewise, McCarthy, Sheehy, and Cook note the ethical, artistic, and forward-thinking

\footnotetext{
15 David A. Cook, Lost Illusions: American Cinema in the Shadow of Watergate and Vietnam 1970-1979 (Berkeley: University of California Press, 2000), 423.

16 The New York Film/Video Council, "What's Happening, Bill Sloan,” press release, 2000, n.p.

${ }^{17}$ Jan-Christopher Horak, "Archiving, Preserving, Screening 16mm," Cinema Journal, 45, 3 (2006), 115.
} 
sensibilities that guided Sloan's work, yet largely fail to specify causes he supported, or types of media he urged The New York Public Library to collect. Lastly, Horak's article is effective at detailing the workflow and unique nature of the Reserve Film and Video Collection, but does not tie Sloan's librarianship or vision to its prevailing success.

Chapters three and four rely on primary sources, which made it possible to paint a more complete picture of Sloan's influence on the Reserve Film and Video Collection, by detailing his many activities that helped integrate moving image media into The New York Public Library: education, film and video programming, community work, and proposals to purchase non-print material. Primary sources used in these chapters fall into two areas: publications (articles, press releases, and reviews) written by Sloan and associated filmmakers, programmers, educators, and librarians during his tenure at both The New York Public Library and Museum of Modern Art; and Sloan's personal documents (notes on his film programs, correspondence, annual reports, project proposals, and unpublished papers), which are currently being stored in nine boxes at The New York Public Library for the Performing Arts under the supervision of Elena Rossi-Snook. 


\section{Chapter 2: Methods}

\subsection{Background}

The research process for this thesis began with the inspection of nine boxes of William J. Sloan's personal documents. One box was found by Elena Rossi-Snook after the closure of Donnell and subsequent move of the NYPL Film Library to the Lincoln Center branch (The New York Public Library for the Performing Arts) in 2008. The remaining eight boxes were donated to The New York Public Library for the Performing Arts by Sloan's daughter, Jennifer Sloan, following his passing on January 28, 2017. All nine boxes were placed in the care of Elena Rossi-Snook and subsequently stored in her office. The documents in these boxes have not been formally accessioned by The New York Public Library.

Upon my arrival at The New York Public Library for the Performing Arts on January 30, 2018, Rossi-Snook entrusted me with the boxes so that I could inspect and consult their contents for this thesis. Over the course of five months, I inspected hundreds of documents either written by Sloan or kept in his possession up until the time of his passing. Most of these documents spanned the period of Sloan's tenure at The New York Public Library. However, a significant number of documents were also produced during his time at the Museum of Modern Art. The latter were reviewed in full but left largely un-cited in this thesis, in the interest of focusing my research on Sloan's work at The New York Public Library.

This chapter will cover, in detail, the inspection process employed to gather, assess, and make use of these primary sources. It also provides a summary of the contents in all nine boxes, limitations that arose over the course of my research, and touches upon potential issues for future 
researchers interested in accessing this material.

\subsection{Document Inspection and Categorization}

The documents contained in the nine boxes are valuable archival objects and, therefore, not permitted to leave The New York Public Library for the Performing Arts. For that reason, a process had to be established to ensure my continued access to them, i.e., to copies of the original documents, over the course of my writing. This method is outlined in this section.

In order to take stock of the available documents and to ensure that an efficient process of studying these documents for my thesis was implemented, each box, after a cursory inspection, was labelled in ascending order from one (1) to nine (9), based on its relevance to my thesis (1 being the most relevant and 9 the least). No specific system for organizing the contents of these boxes was in place when I assumed my work on this project. Moreover, the documents were left in their original boxes following my inspection and not rehoused into new ones. They were not rehoused because of the great number of documents to inspect and far too little time to spend on them over the course of my thesis research and residency at The New York Public Library for the Performing Arts.

The contents of each box can be briefly summarized as follows: (1) Donnell Library Center annual reports, personal correspondence, published and unpublished papers, programming reports, black and white and colour photographs of Sloan, his friends and colleagues, and Teen-Age Video Workshop participants at The New York Public Library, and, lastly, Sloan's papers, reports, and agendas as council member for the Society of 
Cinematologists; ${ }^{18}$ (2) syllabi for courses Sloan taught, film program leaflets, newspaper clippings, Film World, Film News, and Public Library Newsreel journals, and Sloan's work as President of the Film Library Information Council and International Film Seminars, as well as coordinator for The Flaherty Seminar-A single VHS tape, two DVD discs, and a 1983 Joan Clark award and 1977 Indie trophy both received by Sloan; ${ }^{19}$ (3-5) multiple copies of every Film Library Quarterly issue published between 1967 to 1984; (6) original 16mm film catalogues (1959-60, 1966, 1969, 1972), film and video collection addendums (1977, 1978), collected film catalogues (1987), and video collection supplement catalogues (1994), all for the Donnell Library Center (The New York Public Library) —Film and video catalogues (1984), collection addendums (1997), and price lists, all for the Museum of Modern Art-Festival du Court Métrage Clermont-Ferrand program leaflet (1997), Tampere Film Festival leaflet (2009), and a Finnish J. Marttiini fillet knife with no corresponding note or date; (7) film program leaflets (2002-2009), financial reports, film research, email correspondence, published and unpublished papers, all for the Museum of Modern Art-A book of handwritten notes from Sloan's colleagues at The New York Public Library to commemorate his 1980 resignation (dated May 21, 1980), 4 VHS tapes, a single audio cassette, and an undated Clermont-Ferrand medallion; ${ }^{20}$ (8) 2 acetate 16mm films (Beginnings, Europe 1901-1904 and Thomas Edison's Dream of a

\footnotetext{
${ }^{18}$ The Society of Cinematologists was the founding name of what is now The Society For Cinema and Media Studies: The Society For Cinema and Media Studies, "Organizational History," The Society For Cinema and Media Studies, n.d., https://www.cmstudies.org/page/org history [accessed July 21, 2018].

${ }_{19}$ The videotape in Box 2 is labelled, "Peterborough Forest: A Meditstion [sic] on the Living Forest. A Film by Donna Cameron, 2003." The two DVDs are labelled as follows: "Flesh in Ecstasy: 21 min / Casting Gaston Lachaise's Standing Woman: 43 min" (George Stoney and David Bagnall, 2009, n.d.) and "Our Brother Leo: Herb Dratfield, Eunice Dratfield Stack.”

${ }^{20}$ The videotapes in Box 7 are labelled as follows: "Sloan West Virginia Internation [sic] Film Fest. TV Interview Oct. 14, 1987," "Bill \& Gwen Tampere-Kreivita 20.3.98 - Madame EJ Lasse New Yorkissa 19.5-27.5.98 Windsor," "Television in America: First Person Singular William Sloan CUNY Studios 5/9/01," and "Sloan Composite of NYFVC Prog." The audiotape is labelled, "IFS Conversation - December 28, 71' [sic]: Jack Churchill, Maria Grieco de Scioura, F.H. Flaherty, Monica Flaherty Frassetto, Jack Coogan.”
} 
Rarebit Fiend from 1906), a Praxinoscope, medallion from The New York Public Library (dated 1961), and June 26, 1985 issue of Variety concerning the film and video collection at the Museum of Modern Art; (9) Sloan's Master of Library and Information Science certificate from Columbia University (1954), the provisional charter of the Film Library Information Council (October 12, 1967), and various awards and honors, including a Chevalier dans l'Ordre des Arts et Lettres diploma (1988), American Film/Video Festival Leo award (1989) and New York Film/Video Council award (2006). ${ }^{21}$

After assessing the contents of each box, all documents were organized according to the following eleven categories: (1) articles and publications (written by and/or about Sloan); (2) programming information (statistics, notes, advertisements); (3) annual reports (Donnell Library Center, The New York Public Library); (4) project proposals; ${ }^{22}$ (5) policy information (mandates, proposals); (6) personal information (resumes, professional and/or personal background); (7) personal correspondence (written by and/or to Sloan); (8) teaching information (syllabi, course outlines); (9) Film Library Quarterly (publications, contributions); (10) Film Library Information Council (in reference to and/or produced by FLIC); (11) American Library Association (publications, Preview Subcommittee contributions).

Each document was then reviewed in full and either marked as relevant to my research, or immediately returned in its original box. Relevant documents were scanned using iScanner, a

\footnotetext{
${ }^{21}$ Videotapes, $16 \mathrm{~mm}$ films, DVDs, and the audio cassette were not inspected or accessed during this process. I was unable to retrieve more detailed information on Beginnings, Europe 1901-1904 from World Cat, and suspect it may be an orphan film, compilation film, or have an alternate title.

${ }^{22}$ Point (4) refers solely to video project proposals. Sloan's 1969-1970 annual report for the Donnell Library Center contains his earliest known statement regarding the importance of establishing a video collection at The New York Public Library. This topic will be referenced and elaborated on in Chapter 3.
} 
mobile application for multi-page scanning to PDF and JPG formats. ${ }^{23}$ Once scanning had been completed, all documents were printed and arranged within two ring binders, one containing the first eight aforementioned categories, and the other the remaining three.

Sloan retained copies of every issue of Film Library Quarterly he edited from 1967 to 1984. An important section in this publication is Sloan's "Projections," an Editor's Letter on topics and points of view covered within each issue. Occasionally, Sloan contributed articles and writing to this journal over his tenure as its editor: these provide additional insight into his practices at The New York Public Library and his interests in moving image media. Film Library Quarterly was the publication of the Film Library Information Council, an organization spearheaded by Sloan and established in 1967. The Film Library Information Council published the quarterly to establish a regular dialogue among film librarians and to address changing trends in collections management. ${ }^{24}$ Several articles and entries in this publication, which were pertinent to my thesis, were also scanned and included in the second binder.

The rationale behind organizing, scanning, and printing scans of Sloan's original documents, as outlined in this section, was twofold: one, to assemble Sloan's diverse documents, spread across all nine boxes, in a manner that ensured optimal use and quick reference; and two, to have the freedom to read, mark, and annotate documents for the purpose of my thesis.

\footnotetext{
${ }^{23}$ Apple Store Preview, “iScanner - PDF Scanner App,” Apple, https://itunes.apple.com/us/app/iscanner-pdf-scanner-app/id1035331258?mt=8 [accessed May 4, 2018].

${ }^{24}$ William J. Sloan, "Projections 1967-68," Film Library Quarterly 1, 1 (1967), 3.
} 


\subsection{Appendices}

Sloan's syllabi for the courses he taught at post-secondary educational institutions proved to be an invaluable resource for establishing a link between his teaching curriculum and his work at The New York Public Library. Therefore, Appendix A contains a sample of his syllabi for the following courses: "Film Literature, Bibliography and Research" (New York University, 1968), and "Film and the Library" (Pratt Institute, 1970).

The details of Sloan's film programming at, or on behalf of, the Film Library and as president of the Film Library Information Council, were also key to supporting my argument for Sloan's influence upon The New York Public Library and within the film community of the Greater New York area. Therefore, selections of program leaflets, advertisements, and press releases have been included as Appendix B and Appendix C.

Programming statistics, notes, and related correspondence were reviewed frequently over the course of this thesis. Thus, program titles, dates, films, and any additional notes extracted from these documents were tracked within an Excel sheet document, and used as reference for the main body of this thesis. This information had been included as Appendix D. All four appendices are intended as further reference for readers, and to provide insight into primary sources supporting this thesis.

\subsection{Methods: Issues and Limitations}

No cataloguing standard or strict inspection method was applied during my review and organization of the documents within these nine boxes. The reason for not using any cataloguing 
standard is that these standards vary across institutions, and it is still not known which institution will be the final destination for these materials. ${ }^{25}$ Rossi-Snook and I discussed the merits of creating a finding aid to ensure greater access to these documents in the future. However, due to the restrictive timelines of this thesis, few available resources, and the need to assess hundreds of documents in the nine boxes and in an efficient manner, basic archival handling and categorization was employed, and a finding aid was not created. Nevertheless, the film programming spreadsheet (Appendix D) and document scans I completed for this thesis will be given to Rossi-Snook, who will then be able to review them for quick reference in the future. Discussions have since continued as to whether the documents will be deposited with the Library's Manuscripts and Archives Division, which has traditionally maintained materials related to institutional history, or retained at RFVC for research purposes. Yet, this decision remains a peripheral aspect of the work I completed over the course of this thesis.

Moreover, the aforementioned film programming spreadsheet (Appendix D) also contains minor omissions, due to insufficient information within Sloan's documents. While Sloan retained Donnell Library Center film program reports for nearly every year he was the Supervising Film Librarian at The New York Public Library, only those clearly indicating a series he was directly responsible for were included in my spreadsheet. I cross-referenced Sloan's programming reports with program notes, related correspondence and memorandums; however, it was not always clear which programs he was responsible for at Donnell, despite being the one who approved and created each report. Therefore, only programs with direct evidence of Sloan's involvement were

\footnotetext{
${ }^{25}$ The New York Public Library for the Performing Arts generally uses MARC cataloguing standards for its library and archival collections.
} 
utilized considered for my spreadsheet, and of these, only a small selection with detailed information have been included for reference in Appendix D. 


\section{Chapter 3: William J. Sloan and The New York Public Library Film \& Video Collection}

\subsection{An Alert Librarian}

In a 1980 speech, Don Walker, then coordinator of Adult Services at The New York Public Library, cited a brief but important note from the 1957-58 annual report from the Donnell Library Center: "thanks to the arrival of an alert senior librarian to take charge of film service, [...] [Donnell] has successfully included the provision of film information and advisory service within the scope of its responsibilities. We should soon take our rightful place in the educational film field along with other libraries." ${ }^{26}$ Although not mentioned by name, the senior librarian to which Walker referred to in his speech was William J. Sloan (1927-2017), a Canadian expatriate, former high-school teacher, and then-recent graduate of the Master of Library and Information Science program at Columbia University in New York. Sloan had been quickly promoted from his entry-level position in the Mid-Manhattan branch Picture Collection to the first film librarian at The New York Public Library, a fortuitous career advancement that he would later describe as "just something [he] fell into in the 1950s.",27

Prior to joining The New York Public Library, Sloan, and his wife, Gwen, were known as freelance photographers. Their most noteworthy credit was a series of portraits in Some Twentieth Century American Composers, a bibliography edited by John Edmund and Gordon Boelzner and published by The New York Public Library in $1959 .{ }^{28}$ It was Sloan's experience and knowledge of photography that secured him his first position at The New York Public

\footnotetext{
${ }^{26}$ Don Walker, "Speech made by D. Walker - Coordinator of Adult Services at a Going Away Party for Bill Sloan on May 21, 1980," [May 21, 1980], William J. Sloan Documents, New York Public Library, New York [hereafter cited as Walker, Speech, Sloan Documents], 1.

${ }^{27}$ Mary Wade Burnside, "Librarian Promotes Obscure Films,” The Charlotte Gazette, Oct. 2, 1987, n.p.

28 "East Side Documentary Film, “ The Villager, November 19, 1959, 8.
} 
Library Picture Collection, where he reportedly handled nearly 3,000,000 photographs between 1954 to $1957 .{ }^{29}$ Sloan believed that libraries back in the 1950 s and early 1960 s tended "to think of photographs as having a relation to film," and this, in turn, led to his promotion to Supervising Film Librarian at the Donnell Library Center in $1958 .{ }^{30}$ Indeed, the film collection of the Library of Congress was initially handled by its Prints and Photographs Division, following its transfer from the Stack and Reader Division of the LOC Reference Department Office in $1961 .{ }^{31}$

Little information exists to mark the occasion of Sloan's promotion, however, Walker's 1980 speech also cites a newsletter from The New York Public Library dated February 13, 1958, which identifies Sloan as the new Supervising Film Librarian at Donnell and includes a brief overview of the Film Library in its earliest stages:

On February 10th [The Film Library] opened [...] on the first floor of Donnell. It provides [...] film information and advisory services for $16 \mathrm{~mm}$ educational films previously maintained by the Reader Adviser's Office. It also incorporates the film booking service and the collection of over 200 [...] 16mm educational films which have been at Donnell for the last two years. William Sloan is the Supervising Film Librarian." ${ }^{32}$

Less than a month after the Film Library opened, Sloan reported a staggering $40 \%$ increase in film circulation. ${ }^{33}$ Word had spread quickly that Donnell was "the sole source in the [New York] area where individuals could obtain free nonsponsored [sic] films of cultural value on a variety of subjects. ${ }^{\prime 34}$ By 1959, the Film Library collection had grown to include $27016 \mathrm{~mm}$ prints with

\footnotetext{
${ }^{29}$ Archer Winsten, "Rages and Outrages," The New York Post, December 13, 1965, 41

${ }^{30}$ Ibid., 41.

31 "Scholar and Screen: Notes on the Motion Picture Collection of the Library of Congress," The Quarterly Journal of the Library of Congress 21, 4 (1964), 266.

${ }^{32}$ Walker, Speech, Sloan Documents, 1.

${ }^{33}$ William J, Sloan, "Film Library: Annual Report 1957-58," 1958, William J. Sloan Documents, New York Public Library, New York, n.p.

${ }^{34}$ Ibid., n.p.
} 
475 films being circulated and viewed by over 30,000 users per month. ${ }^{35}$ Sloan would see to it that the collection continued to expand its size and reach over the next two decades, with his 1978 annual report boasting 2,500 titles, 4,000 16mm film prints, 350 videocassettes, and 37,276 monthly users at Donnell. ${ }^{36}$

According to Sloan, Film Library users were known to include "community centers, day care centers, senior [citizen] groups, cub scouts, hospitals, museums, labor unions, churches, [...] prisons," and individuals, particularly teenagers, "[borrowing] films for home viewing." ${ }^{37}$ As interest in "film as an art form" grew in the mid 1960s, Sloan increased the number and variety of film programs that were exhibited for patrons at Donnell and the Branch Libraries of New York City, who, in turn, began to make up the majority of Film Library users. ${ }^{38}$ Indeed, Sloan reported that 25,992 of the 37,276 total users in 1978 were those attending films at Donnell. ${ }^{39}$ As reported by Public Library Newsreel in 1961, Donnell initially featured a sole 278-seat auditorium where screenings of film programs were held. ${ }^{40}$ However, in 1976, Sloan oversaw the construction of an adjoining Video/Film Study Center, which allowed film programmers, researchers, filmmakers, video artists, and the public to "view and study [...] films and videotapes" at The New York Public Library for the first time. ${ }^{41}$ The center, where individual users or groups could view $3 / 4$ " cassettes, $16 \mathrm{~mm}$ and $8 \mathrm{~mm}$ prints, and complete video transfers

\footnotetext{
${ }^{35}$ William J. Sloan, “Today's Public Libraries Aid Cultural, Educational Development of Community,” Film World, 15,5 (1959), 214.

${ }^{36}$ William J. Sloan, “Donnell Film Library: Annual Report 1977-1978,” 1978, William J. Sloan Documents, New York Public Library, New York [hereafter cited as Sloan, "Annual Report 1977-1978," Sloan Documents], n.p.

${ }^{37}$ William J. Sloan, "The Donnell Center Film Library Busily Serves New York," Film News 18, 3 (1961), 15.

${ }^{38}$ William J. Sloan, "Film Library: Annual Report 1964-65," 1965, William J. Sloan Documents, New York Public Library, New York, 1.

${ }^{39}$ Sloan, "Donnell Film Library: Annual Report 1977-1978," Sloan Documents, n.p.

40 "The New York Film Library Offers Wide Range of Services," Public Library Newsreel, n.d., 2.

${ }^{41}$ William J. Sloan, “Donnell Film Library: Annual Report 1976-1977,” 1977, William J. Sloan Documents, New York Public Library, New York, n.p.
} 
from $1 / 2$ " reel-to-reel tape to $3 / 4$ " cassette, effectively characterized The New York Public Library as a fulcrum of "the video revolution," and ensured its relevance amidst funding cutbacks for audio-visual departments at public libraries. ${ }^{42}$ This extraordinary increase in moving image media collected and circulated by The New York Public Library, as well as Donnell becoming a hub for film programming and moving image media education in New York City over the span of two decades, was the direct result of Sloan's efforts. Edwin S. Holmgren, then Branch Library System Director for The New York Public Library, confirmed my assessment of Sloan in his reply to Sloan's notice of resignation on May 1, 1980: "Your contributions over the years have been outstanding, and the high quality of the collections and services offered by the Film Library and the Video/Film Study Center can be attributed [...] to your hard work and professional leadership. ${ }^{{ }^{43}}$ Holmgren also noted that patrons of The New York Public Library had benefited most from Sloan's knowledge and great interest in "non-print media." 44

\subsection{Early Years and Influence on the Film Library}

Sloan was seen as a pioneer of media librarianship in the first decade of his career at The New York Public Library, with leading film critic Archer Winsten praising his innovative mindset, commitment to promoting film, and inability "to say no to anything resembling a worthy cause." ${ }^{95}$ Experimental filmmaker, film critic, and founder of Anthology Film Archives

\footnotetext{
${ }^{42}$ Deirdre Boyle, "Video: What Librarians Do with a Recycle Medium," American Libraries 7, 9 (1976), 584.

${ }^{43}$ Edwin S. Holmgren, Edwin S. Holmgren to William J. Sloan, May 1, 1980, letter, William J. Sloan Documents, New York Public Library, New York, n.p.

${ }^{44}$ Ibid., n.p.

${ }^{45}$ Winsten, "Rages and Outrages," 41.
} 
Jonas Mekas would also laud the Film Library at Donnell as early as 1960, writing in the Village Voice:

The other day I spent an evening with a group of film students. They discovered something very few New Yorkers know: namely, that from the Donnell Library you can rent films for nothing. All you need is a projector. Documentaries, experimental films, movies by Pare Lorentz, [Williard] Van Dyke, Ian Hugo, Shirley Clark, and a great number of other short items — all are available for your close scrutiny. ${ }^{46}$

Perhaps the most significant praise Sloan would receive early in his career would be from Marilyn Iarusso of The New York Public Library Office of Children's Services. Iarusso, a children's librarian with a strong interest in film and video collections, knew only too well that libraries were "notoriously [prejudicial] towards print services over film." ${ }^{\text {M7 }}$ Moreover, her sentiments on public access to media collections echoed Sloan's, believing that every effort should be taken to provide young audiences with "opportunities to see films which can speak to them." ${ }^{48}$ In her 1972 special collections report, Iarusso commended Sloan for dramatically expanding the scope of the Film Library, and improving administrative services at Donnell. Most importantly, she emphasized Sloan's beliefs that public use of films should be the determining factor in "purchase patterns," and that more well-selected titles should be bought "in greater duplication" to ensure that The New York Public Library collected only "special or non-commercial films which [were] purchased by only four or five public libraries in the country."49 Iarusso's report, therefore, demonstrates Sloan's perspectives on collection management at public libraries in general, and more specifically on the film collection at The

\footnotetext{
${ }^{46}$ Jonas Mekas, "Movie Journal," The Village Voice, March 16, 1960, n.p.

47 Marilyn Iarusso, "Film Selection and Programming for Children in Public Libraries," Children's Film Programming: A Handbook, (New York: Highsmith Press, 1992), 53

${ }^{48}$ Ibid., 53.

${ }^{49}$ Marilyn Iarusso, "Report on a Special Collection: The Film Library," 1972, William J. Sloan Documents, New York Public Library, New York, 4.
} 
New York Public Library, considering of utmost importance the relevance of the content in a collection to the community it served. Sloan's "careful selection practices" built the Film Library (now Reserve Film and Video Collection) into a strong collection and led it to become a vital center for moving image media, "impressive for its scope and depth" and "unique among American public libraries, and [...] archives held within major American museums and universities." $" 50$

Moreover, it was Sloan's insistence on circulating high quality films and videos, otherwise restricted to museums and archives, that made The New York Public Library a uniquely accessible media center. In a 1969 article for Metropolitan, David Preiss identified the Film Library at Donnell as proof of public library audio-visual departments being the "best sources for art film," surpassing the film collections of neighbouring institutions such as the Museum of Modern Art. ${ }^{51}$ Sloan would further build upon this distinction by helping establish the aforementioned Video/Film Study Center in 1976, a media studies center fully accessible to the public. This study center at Donnell set The New York Public Library apart from study centers at the Museum of Modern Art, Library of Congress, and New York University, which Sloan viewed as restrictive and accessible only to researchers and graduate students. ${ }^{52}$

In addition to integrating moving image media with print material at The New York Public Library, Sloan sought to utilize it in a manner befitting its unique mode of communication. In his 1969 paper entitled "Film and the Public Library: Selection and

\footnotetext{
50 The New York Public Library, "Reserve Film and Video Collection," The New York Public Library, www.nypl.org/ about/locations/lpa/circulating-collections/reserve-film [accessed May 20, 2018].

${ }^{51}$ David Preiss, “Art Films: A Fresh Dimension,” American Artist 33, 7 (1969), 3.

${ }^{52}$ William J. Sloan, William J. Sloan to Don Walker, January 3, 1976, letter, William J. Sloan Documents, New York Public Library, New York, NY, n.p.
} 
Programming," Sloan asserted that in the "era of image media" and "information technology," public libraries should examine "new tools to aid them in meeting their educational goals," film being "chief among these." ${ }^{53}$ The media theories of Canadian philosopher and educator Marshall McLuhan were also emphasized by Sloan as vital to how public libraries should utilize non print material. ${ }^{54}$ With this context in mind, Sloan believed that the film collection at Donnell could have "great variety and depth paralleling the [...] book collection" of The New York Public Library. ${ }^{55}$

As indicated by Sloan in a 1959 issue of Film World, his point of view was not necessarily at odds with other librarians' perception of film as a "natural outgrowth of public library [...] education programs," and a medium that could "quickly introduce new ideas or lay a common foundation" equally well or even better than print materials. ${ }^{56}$ Where Sloan parted ways with other librarians, was in his belief that "horizon widening films that provoke the imagination and provide new insight" could fill "an effective role in furthering [...] public libraries' educational goals. ${ }^{157}$ For Sloan, there were four distinct questions every film librarian should ask themselves: "[What] are we showing? How informative are our [films]? How incisive? How provocative?" ${ }^{58}$ In effect, he saw inherent educational value in collecting, promoting, and

\footnotetext{
${ }^{53}$ William J. Sloan, "Films and the Public Library: Selection and Programming," paper presented at the IFLA/FIAB Conference, Copenhagen, August 1969, William J. Sloan Documents, New York Public Library, New York [hereafter cited as Sloan, "Films and the Public Library," 1969, Sloan Documents], 1.

${ }^{54}$ Sloan taught Marshall McLuhan's media theories in his courses. Specifically, his course "Film and the Library" at Pratt Institute. (Please see Appendix A). His interest in McLuhan might partially explain Sloan's interest in current and emerging moving image media, as well as the value of including these media of communication in library collections, alongside the older communication media, such as print and manuscript. Although McLuhan's theories might be a valuable angle to pursue in connection with Sloan's interest in moving image media and the changing role of libraries in the age of information technologies, it is beyond the scope of this thesis.

${ }^{55}$ Sloan, "Films and the Public Library," 1969, Sloan Documents, 5

${ }^{56}$ Sloan, "Today's Public Libraries Aid Cultural, Educational Development of Community," 214.

${ }^{57}$ William J. Sloan, "Films in the Sixties: The Search for Excellence," Illinois Libraries 48 (1966), 95.

${ }^{58}$ William J. Sloan, "Projections," Film Library Quarterly 7, 4 (1974), 3.
} 
programming provocative or experimental works for the public, as opposed to those made specifically for educational purposes.

Moreover, Sloan believed that film selection criteria for library collections should be dependent on the personal judgement of a librarian, who determines its cultural, creative, and educational value in relation to changing societal attitudes. In his review of Julien Bryan's Tropical Africa (1961), Sloan noted that while the film "reveals how the fabric of society is changing" in regards to race relations, its educational content was ultimately too oversimplified and lacking in substance:

No attempt is made to be specific about current problems making the headlines. Rarely is a country or leader mentioned by name. In the attempt to find common denominators for the entire area under study there is at times a tendency to over-simplify. Also, [Bryan's] affirmative, even optimistic stand, particularly as it relates to race relations, seems not to be fully justified by events in many sections. ${ }^{59}$

While Sloan deemed the film suitable for programming in public libraries, he believed it was appropriate only for high school or college-aged students as a "springboard" to more complex topics. His point of view was decidedly at odds with other reviews by journalist Howard Thompson and film critic Jean Walrath from The New York Times and The Rochester Democrat and Chronicle respectively, both of whom lauded the film. Walrath particularly praised Bryan's "intelligence and sympathy" towards his subjects, and the relevance of the film to a "world in social and scientific advancement."60 What becomes clear upon comparing these reviews is Sloan's perspective as both an educator and librarian on what makes a strong film and fitting for

\footnotetext{
${ }^{59}$ William J. Sloan, "3 Recent Reviews of the film "Tropical Africa," press release, August 1961, William J. Sloan Documents, New York Public Library, New York, n.p.

${ }^{60}$ Jean Walrath, "3 Recent Reviews of the film "Tropical Africa," press release, August 1961, William J. Sloan Documents, New York Public Library, New York, n.p.
} 
a public library collection, a perspective fundamentally guided by social conscience and desire to promote films with balanced views.

Sloan's progressive political views and sense of social justice determined the direction and sustained the quality of the Film Library. After being criticized by Carmen Diodati, an Italian-American patron of The New York Public Library, for not accepting Phillip F. Messina's emigration-centered documentary Mamma (1975) into the collection, Sloan responded with insistence upon quality: "It raises a continuing dilemma we face with ethnic films. If we [collect] a film that is considerably below our standards, we are condescending to that particular group, and members of it often feel insulted. Messina's film is below standard. It can be effective if a person like yourself goes along with the film, but it does not stand on itself. ${ }^{, 61}$ In her original letter, Diodati indicated that although she was aware Sloan "did not deem the film worthy [...] at least in terms of subject matter," she urged him to reconsider in order to avoid a public relations debacle with the Italian-American community. ${ }^{62}$ Sloan remained firm in his resolve, but attempted to appease Diodati by explaining that he and his staff were prepared to preview a documentary by another important Italian-American filmmaker, Italianamerican (1974) by Martin Scorsese. ${ }^{63}$ A $16 \mathrm{~mm}$ print of this film was later purchased by Sloan, which remains in the RFVC today.

Although he faced occasional backlash for such decisions, New York Film/Video Council president Howard Weinberg wrote in 2000 that Sloan's opinionated and political nature

\footnotetext{
${ }^{61}$ William J. Sloan, William J. Sloan to Carmen Diodati, April 27, 1977, letter, William J. Sloan Documents, New York Public Library, New York [hereafter cited as Sloan, Sloan to Diodati, April 27, 1977, Sloan Documents], n.p. ${ }^{62}$ Carmen Diodati, Carmen Diodati to William J. Sloan, April 22, 1977, letter, William J. Sloan Documents, New York Public Library, New York, n.p.

${ }^{63}$ Sloan, Sloan to Diodati, April 27, 1977, Sloan Documents, n.p.
} 
was grounded in his belief "that the quality of our media affects the quality of our democracy." Sloan maintained that public librarians had a responsibility "to search out and find the films [...] that [could] help individuals make a balanced and mature judgement of issues of public concern." $" 65$

\subsection{Professional Endeavors and Roles}

In addition to his work at The New York Public Library, Sloan maintained a multifarious career that rendered his presence ubiquitous in the New York film community. As early as 1965, Sloan held the following positions and all at the same time: coordinator of film reviews for the American Library Association Booklist and Subscription Books Bulletin; administrator for the Rosenthal Awards in Creative Cinema (1965-66); treasurer of the American Federation of Film Societies; chairman of both the New York Library Association Audio-Visual Materials and Services Committee and of the American Library Association Motion Picture Preview Sub-Committee; and, lastly, council member of the Society of Cinematologists and editor of the Journal of the Society of Cinematologists (1965-67). ${ }^{66}$

Sloan was a prolific film programmer, chiefly responsible for annual American Library Association (ALA) conference screenings, multiple international workshops through the Film Library Information Council, and long-running series at The New York Public Library such as Daytime Films, Evening Films, Filmmaker Speaks, Meet the Maker, and Films on Racism (see Appendix D). In addition, Sloan collaborated with Ted Perry, then Director of the Film

\footnotetext{
${ }^{64}$ Howard Weinberg, "Letter from the Council President," The New York Film/Video Council Newsletter, 2000, 1.

${ }^{65}$ William J. Sloan, "Projections," Film Library Quarterly, 5, 3 (1972), 3.

${ }^{66}$ Sloan, Curriculum Vitae, Sloan Documents, n.p.
} 
Department at the Museum of Modern Art, in programming films for What's Happening, an influential and collaborative series in which films deemed unsuitable for theater and television were programmed. ${ }^{67}$ Furthermore, in 1977, Sloan had become the President of International Film Seminars, an organization that sponsored non-theatrical film festivals. One of these festivals was The Flaherty Seminar, on which Sloan frequently relied as a source for programming material at Donnell. ${ }^{68}$

Addressing how Sloan's many roles connected and were leveraged to support his librarianship is vital to understanding his influence on The New York Public Library. For instance, Sloan's film programming work was intrinsically connected to nearly all of his professional endeavours, including his work at Pratt Institute and New York University, where he taught courses on managing film collections in a then predominately print-based field. Indeed, writing to Frances Flaherty, in an effort to dissuade her from retitling The Flaherty Seminar, Sloan identified himself as "a film librarian who has encouraged extensive programming of [Robert] Flaherty's films in the [sic] New York Public Library's branch system [...], a teacher who uses the Flaherty films with students, and [...] someone who has attended many of the seminars." ${ }^{99}$ Sloan's productive and coordinated involvement in multiple fields allowed him to navigate the bureaucracy of ALA and advocate for groundbreaking films in public libraries, develop library education curriculum that focused on emerging media, program films both nationally and internationally, and create a dialogue between film librarians, all in the service of

\footnotetext{
${ }^{67}$ William J. Sloan, William J. Sloan to Ted Perry, February 23, 1978, letter, William J. Sloan Documents, New York Public Library, New York, n.p.

${ }^{68}$ Deirdre Boyle, "Video in Public Library Service," Film Library Quarterly, 11, 3, (1978).

${ }^{69}$ William J. Sloan, William J. Sloan to Franches Flaherty, December 12, 1971, letter, William J. Sloan Documents, New York Public Library, New York, n.p.
} 
promoting and expanding moving image media at The New York Public Library. ${ }^{70}$

\subsection{Contributions to American Library Association}

In the 1962 annual report for the American Library Association (ALA) midwinter conference, Sloan described the strategy and purpose behind the Motion Picture Preview Sub-Committee: "[The Sub-Committee] participate[s] on the Film Estimate Board of National Organization, which publishes the Green Sheet film reviews. Members of the [Sub-Committee] and guest librarian[s] review [...] films based on novels, plays, and those that are on topical or controversial subjects." ${ }^{71}$ The Green Sheet that Sloan referred to was a monthly publication that consisted of film reviews from numerous educational or community organizations within the United States, and which he coordinated for this sub-committee. Predating the Motion Picture Association of America (MPAA) rating system, this publication was distributed nationally to public libraries, churches, and other non-profit organizations as a guide for selecting films suitable for specific age-groups. ${ }^{72}$

For Sloan, the appeal of contributing to the Green Sheet was that most Hollywood films available for review were, from his perspective, "devoid of aesthetic or cultural value," and thus his "participation on the Film Estimate Board [gave] support to [...] rare films" of real importance. ${ }^{73}$ Sloan believed that the Sub-Committee should focus its energy on "more important

\footnotetext{
${ }^{70}$ Films, programs, and workshops referenced here will be detailed in the following four sections of this chapter.

${ }^{71}$ William J. Sloan, "Report of Committee Activities, July 1961, to June, 1962," 1962, William J. Sloan Documents, New York Public Library, New York [hereafter cited as Sloan, "Report of Committee Activities, July 1961, to June, 1962," 1962, Sloan Documents], n.p.

${ }^{72}$ William J. Sloan, "Report for ALA Midwinter Conference 1967, Motion Picture Preview Subcommittee of the Audio Visual Committee," December 4, 1966, William J. Sloan Documents, New York Public Library, New York [hereafter cited as Sloan, "Report for ALA Midwinter Conference 1967," 1966, Sloan Documents], n.p.

${ }^{73}$ Sloan, "Report of Committee Activities, July 1961, to June, 1962," 1962, Sloan Documents, n.p.
} 
Hollywood films," "foreign imports," and non-fiction and non-theatrical films that would appeal to a "growing audience of young people $[. .$.$] intensely interested in [cinema]." { }^{\text {"4 }}$ Sloan was relentless in advocating for film programming aimed at youth audiences, and emphasized sensibilities of this demographic at length:

[Youth] hate being talked down to and they resist being elevated, educated, or improved. However, they can be inspired [...] Therefore [sic] we try to get films [...] right [for] a variety of young audiences from differing socio-economic backgrounds. The delight of film work with this age group is that preconceptions are not possible and thus the state of the [library] art is kept ever-changing and fluid. ${ }^{75}$

Sloan's commitment to inspiring and educating young audiences reflected strongly Marilyn Iarusso's belief that libraries "become the place in our society where [youth] can encounter fine films appropriate to their interests." ${ }^{" 76}$ Indeed, while keenly aware that the Green Sheet was primarily used to select family-appropriate material, Sloan ensured that the Sub-Committee also invited children's librarians to highlight films with more educational value than the "banal, trivial" programming otherwise recommended for pre-teen audiences. ${ }^{77}$ Thus, the ALA Preview Sub-Committee was, in Sloan's words, "probably one of the more sophisticated" contributors to the Green Sheet publication. ${ }^{78}$

However, as a film librarian primarily interested in non-theatrical and non-commercial cinema, Sloan often maintained a skeptical stance towards the Green Sheet. In fact, in 1967, he wrote that even the "ALA [had] been uncertain as to whether to continue participating" in a

\footnotetext{
${ }^{74}$ William J. Sloan, "Annual Report for ALA Midwinter: Motion Picture Preview Subcommittee of the Audio-Visual Committee," 1965, William J. Sloan Documents, New York Public Library, New York, n.p.

${ }^{75}$ Sloan, "Films and the Public Library," 1969, Sloan Documents, 3 b.

${ }^{76}$ Iarusso, "Film Selection and Programming for Children in Public Libraries," 54.

${ }^{77}$ Sloan, "Report for ALA Midwinter Conference 1967," 1966, Sloan Documents, n.p.

${ }^{78}$ Ibid., n.p.
} 
publication so entrenched in "show-biz" values. ${ }^{79}$ Nevertheless, Sloan was mindful of ALA's lacking participation in areas outside of print material, and saw the sub-committee's involvement with the Green Sheet as a way of bridging this gap:

[The] ALA makes hardly any contribution in the entire area of the motion picture medium. And movies, along with television, are one of the strongest molders of public attitudes, especially among the young in our contemporary civilization. In a small way the preview subcommittee can speak out for those occasional films that do contain truth and beauty and hopefully do a little molding in the other direction. ${ }^{80}$

In addition to his involvement with the sub-committee and Green Sheet, Sloan was instrumental in having the ALA adapt to film by appealing to his colleagues in the field. As early as 1960 , Sloan was in regular contact with Marsha R. Porte, chairman of the ALA Noon-Day Program Committee and head of the audio-visual department of the Dallas Public Library. Recognizing her as a like-minded and astute film librarian, Sloan suggested films to Porte that he believed would demonstrate the importance of film to the ALA. After receiving Porte's initial list of primarily instructional and Disney-produced films in a program she was preparing for an ALA conference in Montreal, Sloan replied with the following feedback: “Aren't we trying to bring before librarians the very best in filmmaking in order to spread the idea that films can be an important part of a library collection[?] Most librarians feel that films are an ephemeral if not altogether dreary business and I feel that too many films on [your] list will only emphasize this attitude on their part." ${ }^{\circledR 1}$

\footnotetext{
${ }^{79}$ Sloan, "Report for ALA Midwinter Conference 1967," 1966, Sloan Documents, n.p.

${ }^{80}$ Ibid., n.p.

${ }^{81}$ William J. Sloan, William J. Sloan to Marsha R. Porte, March 23, 1960, letter, William J. Sloan Documents, New York Public Library, New York, n.p.
} 
While not altogether convinced by Sloan's insistence on including documentary works such as Hans Namuth's Jackson Pollock (1951), Porte concurred that "the films we want to show should be provocative and stimulating [...] and many of the titles on the [...] list do not fulfill this description. ${ }^{" 82}$ Porte also acknowledged the divide between film and print librarians on the ALA committee, the latter often suggesting the "duller" and "purely informational" films largely criticized by Porte and Sloan. ${ }^{83}$ Despite their differences, Sloan and Porte agreed that an ALA screening should contain works that, in Porte's words, "[were] stimulating in content and of the highest possible technical quality" if films were to be regarded as equal to print material ${ }^{84} \mathrm{After}$ weeks of corresponding and collaboration, Sloan submitted program notes for films he and Porte had agreed upon for the 1960 ALA conference, including international documentaries produced by the National Film Board of Canada, such as John Feeney's The Living Stone (1958) and Julian Bigg's Family of Ghana (1955), as well as American animation director John Hubley's experimental short Moonbird (1959), and the cinéma vérité-inspired children’s film, My Own Yard to Play In, produced in New York by Films Media Group. Sloan concluded his letter to Porte by enthusiastically complimenting her series, calling it, "far superior to any that have been put on before at ALA." ${ }^{15}$

\footnotetext{
${ }^{82}$ Marsha R. Porte, Marsha R. Porte to William J. Sloan, April 5, 1960, letter, William J. Sloan Documents, New York Public Library, New York, n.p.

${ }^{83}$ Ibid., n.p.

${ }^{84}$ Marsha R. Porte, Marsha R. Porte to ALA Noon-Day Program Committee, April 5, 1960, letter, William J. Sloan Documents, New York Public Library, New York, n.p.

${ }^{85}$ William J. Sloan, William J. Sloan to Marsha R. Porte, May 4, 1960, letter, William J. Sloan Documents, New York Public Library, New York, n.p.
} 


\subsection{Film Library Information Council and Film Library Quarterly}

The Film Library Information Council (FLIC) was officially established on May 12, 1967 at the Biltmore Hotel in New York City, where 78 film and audio-visual librarians were gathered following that year's American Film Festival. ${ }^{86}$ Variety reported that Sloan had been elected chairman of the council, with fellow film librarians Joan Clark, Dorothy Lynch (New York), Marsha R. Porte (Texas), Charlotte Shatkin (New Jersey), Virginia Beard (Ohio), Esme Dick (Connecticut), Violet Myer (Maryland), and Joseph B. Runey (Virginia) serving as board members and representatives of "the nation's major libraries." ${ }^{177}$ The council was developed in response to what Public Library Newsreel described as "widespread need for a communications link [amongst] film librarians." ${ }^{" 88}$ Indeed, until the formation of FLIC, reports on film libraries and their administrative requirements, issues, and concerns were scattered or otherwise non-existent. As explained by Joseph W. Palmer, then Assistant Professor of Library Science at the California State University of Fullerton, the ALA Audio-Visual Committee's limited scope and publication history created a severe lack of documentation for film collections ${ }^{89}$ Therefore, establishing an organization that addressed what Joan Clark referred to as "administrative A-V materials and services, state legislation affecting film librarians, statistics on materials and budgets, [...] space requirements," and most importantly, "integration of A-V with total library programs," was necessary for the legitimacy and survival of library film collections in the late 1960s and beyond..$^{90}$

\footnotetext{
86 “Film Librarians Organize: Might Help U.S. Build Archives," Variety, May 31, 1967, 11.

${ }^{87}$ Ibid., 11.

88 "New Public Film Librarians Organization Established," Public Library Newsreel, n.d., 1.

${ }^{89}$ Joseph W. Palmer, ““14-'74: Decades of Service,” Film Library Quarterly, 8, 1 (1975), 20.

90 "New Public Film Librarian Organization Established," 1.
} 
While FLIC began as a discussion led by James Limbacher, president of the Educational Film Library Association, it was Sloan who would leave an indelible mark on how it operated. According to minutes gathered from the 1967 meeting, Limbacher suggested the idea of forming a film library organization that could operate in relationship with ALA, or instead function as a "completely autonomous" entity. ${ }^{91}$ Sloan was quick to respond that if any film library organization were to be established, it should "work closely with ALA," as this would allow for better "[communication] with other members of the profession." ${ }^{\prime 2}$ At the same time, Sloan lamented the bureaucracy and inflexibility of the ALA, as well as its Audio-Visual Committee having little to no film experience. To overcome these limitations of ALA, Sloan suggested a twofold solution: first, that a film library organization be formed to work with and influence the ALA; and secondly, that an associated publication be established, which Sloan volunteered to edit and manage, to strengthen communication amongst film librarians. ${ }^{93}$ The organization in question would become the Film Library Information Council and the publication Film Library Quarterly.

A press release for the Film Library Information Council was later disseminated, indicating that since existing "library organizations were book oriented to the expense of non-print materials, and film/AV organizations were dominated by educators whose chief interest lay in curriculum-related materials," FLIC was established to meet "special public

\footnotetext{
${ }^{91}$ Minutes of the Film Library Organization, Biltmore Hotel, New York, May 12, 1967, William J. Sloan Documents, New York Public Library, New York, 10.

${ }^{92}$ Ibid., 11.

${ }^{93}$ Ibid., 12.
} 
library needs." ${ }^{94}$ In the same press release, Film Library Quarterly was announced as "the official voice of FLIC," and the following description outlined its ambitious scope:

[Film Library Quarterly] span[s] the interests of the film library field, including articles on filmmakers, the documentary, film art and the avant-garde, film history, news media, educational television, film and book reviews, and poetry. It is also concerned with the broad issues of philosophy of service, administration, collection building, and censorship in libraries. ${ }^{95}$

The first issue of this publication featured the first of many editorial introductions by Sloan, who emphasized that FLIC and Film Library Quarterly were not only concerned with film, but also "the entire field of non-print library service including all [...] new media appropriate for public library programs," such as the emerging video technology. ${ }^{96}$ The publication was funded largely through donations from associated libraries, as well as ad revenue generated by representatives of the film industry. In a 1968 issue of Film Library Quarterly, Sloan noted that it was "highly unusual" for the film industry to support a journal of this type, and therefore indicative of the professionalization and rapid development of the film library field, which were the outcomes of then recently established FLIC. ${ }^{97}$

Film Library Quarterly articles and editorial pieces were characteristic of Sloan's commitment to promoting moving image media and often inspired by issues he faced as Film Librarian at The New York Public Library. For instance, in his Editor's Letter for a 1971 issue of $F L Q$, Sloan focused upon the withdrawal of controversial films from the Los Angeles County Library System due to pressure from a far-right political group in California. The films were

\footnotetext{
${ }^{94}$ Film Library Information Council, "FLIC: The Film Library Information Council," press release, n.d., William J. Sloan Documents, New York Public Library, New York, n.p.

${ }^{95}$ Ibid., n.p.

${ }^{96}$ Sloan, "Projections 1967-68," FLQ 1, 1, 3.

${ }^{97}$ Ibid., 3.
} 
eventually returned to the LA County Library; however, Sloan used his letter to explain how film librarians could stand up to such threats, including familiarizing oneself with library censorship policy, previewing films likely to face backlash, and ensuring communication with FLIC headquarters for legal advice..$^{98}$

\subsection{Teaching Career}

In his 1968 article for Film Library Quarterly, Vincent J. Aceto, then associate professor of Library Science at the State University of New York, praised Sloan's efforts to introduce moving image media into library curriculum at the Pratt Institute, where he taught "Audio-Visual Services and Materials," "Multi-Media Materials and Services," "Film and the Library," and “Television and Libraries" from 1967 to 1979:

For too long library schools have failed to recognize that film neither replaces nor augments books but is a legitimate form of communication which must be appreciated and understood on its own terms [...] Except for Bill Sloan's efforts at Pratt [...] the study of film as film — as an art form that has integrity in itself—is almost totally ignored. ${ }^{99}$

Of all of his courses at Pratt, Sloan's 1970 syllabus for "Film and the Library" (Appendix A) is the best example of the efforts to which Aceto refers. In this syllabus, Sloan explains that the course will explore "film and its role in library service," as well as "the historical development of films, their evaluation, organization, use, and relationship to print and other [non-print] media." ${ }^{100}$ Moreover, Sloan states that students will learn about the "changing philosophy of public libraries to a more activist role as centers for community educational and cultural activity [...]

\footnotetext{
${ }^{98}$ William J. Sloan, "Projections," Film Library Quarterly 4, 2, 1971, 2-3.

${ }^{99}$ Vincent Aceto, "Opening New Doors to Film Literacy," Film Library Quarterly, 1, 3, 1968, 36.

${ }^{100}$ William J. Sloan, "Film and the Library," syllabus, 1970, William J. Sloan Documents, New York Public Library, New York [hereafter cited as Sloan, "Film and the Library," Sloan Documents], 1.
} 
making extensive use of films," and concludes that "this is, indeed, the justification for including a [film and library] course in a library school curriculum." ${ }^{101}$ International film history, particularly in relation to non-theatrical cinema, was a major focus of this course. By mid-term, the focus would shift to new media, specifically videocassette systems and their future "implications for libraries." 102

There are notable similarities between the contents of coursework laid out in this syllabus and Sloan's 1970 annual report for the Film Library. For instance, commenting on film use in The New York Public Library branch programs, Sloan wrote, "I feel NYPL is a leader in using films in neighbourhood libraries so that they may take an activist role in community life." ${ }^{103} \mathrm{He}$ also details the implications of a recent Library Services and Construction Act (LSCA) grant given to The New York Public Library and how this grant would allow the Film Library to acquire tape and cartridge systems: "Hopefully [this] will make it possible for the Library to play an increased role in providing continuing education since the cartridges seem to offer unlimited opportunities for home study." ${ }^{104}$ Evidently, Sloan's work at Donnell informed his perspective on teaching moving image media both within and outside The New York Public Library.

Sloan's foresight of the potential of new moving image media in public libraries also caught the eye of George Amberg, professor and founder of the graduate department of Cinema Studies at New York University, whose recommendation helped Sloan land his first appointment as sessional film lecturer at NYU in $1968 .{ }^{105}$ Five years later, Sloan was given a teaching

\footnotetext{
${ }^{101}$ Sloan, "Film and the Library," Sloan Documents, 1.

${ }^{102}$ Ibid., 1.

${ }^{103}$ William J. Sloan, "Film Library Annual Report 1969-70,” 1970, William J. Sloan Documents, New York Public Library, New York, n.p..

${ }^{104}$ Ibid., n.p.

${ }^{105}$ William J. Sloan, Monroe Lippman to William J. Sloan, May 13, 1968, letter, William J. Sloan Documents, New York Public Library, New York, n.p.
} 
position at the University Film Study Center at Hampshire College for its Summer Institute of Film and Photography. Here he taught "Film Evaluation and Selection," which was intended for "teachers, librarians, media specialists, youth group leaders, and those involved in adult education" to examine "style and meaning" in non-narrative film. ${ }^{106}$ It was Sloan's acute understanding of both cinema studies and library education that made him an effective and forward-thinking public librarian. As stated by Amalie Rothschild, a documentary filmmaker whose films Sloan often programmed at The New York Public Library, "Many librarians see films in a vacuum, without any real understanding of the nature of filmmaking, how it is a creative endeavour and means of communication" outside of print material. ${ }^{107}$ In this regard, Sloan's work pushed the envelope for how public libraries and Library Science curriculum could conceptualize and use moving image media by emphasizing its unique aesthetic qualities and means of communication.

\footnotetext{
${ }^{106}$ William J. Sloan, “Introduction to Film Study: An Examination of Non-Narrative Film,” syllabus, 1973, William J. Sloan Documents, New York Public Library, New York, 1.

${ }^{107}$ Deirdre Boyle, “A Voyage of Discovery for Librarians,” American Libraries 8, 11 (1977), 635.
} 


\section{Chapter 4: Libraries as "Centers for Community Educational and Cultural Activity"}

\subsection{Perspectives on Library Film Programming}

In a Fall 1968 issue of $F L Q$, Sloan provided a comprehensive list of reasons to develop library film programs, emphasizing that public libraries should become media centers for the community they serve: (1) library programs "are tailored to meet their communities specific needs," and also tend to screen a variety of films in different styles; (2) library films are typically not screened on television or in theaters; (3) a projected film is far more aesthetically pleasing than watching a film on television; (4) viewing a film as a group "can be psychologically more rewarding" than viewing one while home alone; (5) young audiences have a better chance of seeing an intellectually engaging film at a public library; and (6) public library film programs appeal to more discerning audiences that view "film as an art form." 108 Most importantly, as a contemporary and popular medium, programming film in public libraries brought greater attention to library service in the 1960s and 1970s. As Sloan observed in 1972, feature film programs significantly increased the number of patrons visiting a public library, which was "recognized and supported by library administrators" who ensured adequate financial support was in place for film and video collections as a result. ${ }^{109}$

\subsection{Film Programming, Workshops, and Seminars}

Nonetheless, what Sloan valued most was that film programming, whether within or outside public libraries, be challenging, provocative, and employed for an educational purpose.

\footnotetext{
${ }^{108}$ William J. Sloan, “Projections,” Film Library Quarterly 1, 4 (1968), 2.

${ }^{109}$ William J. Sloan, "Projections,” Film Library Quarterly 5, 4, (1972), 3.
} 
Echoing his colleague Marsha R. Porte's sentiments that film be "presented as an example of a given aspect of the art of filmmaking," Sloan would become well-known throughout New York City as a programmer of genres on the fringe of popular cinema, such as independent, avant-garde, documentary, experimental, or otherwise non-commercial film. ${ }^{110}$ Moreover, although he recognized the need for programming a variety of different genres and styles, Sloan consistently argued for the exhibition of art films at The New York Public Library and abroad. In his 1974 editorial piece for Film Library Quarterly, Sloan makes the case for regularly programming "personal, avant-garde, [or] film-as-art" cinema in public libraries, acknowledging that although such genres were thought of as appealing only to "elitist" or "sophisticated" art museum crowds, they could serve just as much of an educational purpose as programming for children, teenagers, seniors, and special interest groups. ${ }^{111}$ This became Sloan's guiding philosophy as film programmer.

On March 11, 1968, Sloan made a major impression on the fourth iteration of the Freedom Forum series, selecting films for its "Underground Film" program from The New York Public Library film collection. ${ }^{112}$ Screened at Linton High School in Schenectady, New York, Sloan's program included avant-garde works such as Kenneth Anger's Scorpio Rising (1963), Stan Vanderbeek's Breathdeath (1964), and Bernard Stone's 12-12-42 (1967). ${ }^{113}$ The program concluded with "a discussion of the films and the history and significance of the underground film movement" led by Sloan. ${ }^{14}$ Gordon Boyd of The Schenectady Gazette reported that nearly

\footnotetext{
${ }^{110}$ Marsha R. Porte, "Fundamentals of Evaluation," Film Library Quarterly 5, 4, (1972), 3.

${ }^{111}$ William J. Sloan, "Projections," Film Library Quarterly 7, 2 (1974), 4.

${ }^{112}$ Freedom Forum, "25th Anniversary Season 1967-1968: The “Underground' Film," press release, March 9, 1968, William J. Sloan Documents, New York Public Library, New York, n.p.

${ }^{113}$ Ibid., n.p.

114 "Freedom Forum to Show 3 Films Monday," The Schenectady Gazette, March 9, 1968, n.p.
} 
400 people had attended the program, with nearly " 400 varying ideas of what the underlying themes were" during the follow-up discussion between Sloan and members of the audience. ${ }^{115}$ Despite its "audio-visual psychic overhaul," the audience appeared receptive to the screening, as well as Sloan's lecture on the "independent or new film" movement that had begun in New York only eight years prior, but was still relatively unknown by the general public. ${ }^{116}$ The success of "Underground Film" was indicative of Sloan's steadfast belief that there would always be "a lively and intellectually-alert audience" for provocative material wherever there was "an art community or [...] large university." ${ }^{117}$ Most importantly, the program showcased Sloan's efforts to demystify the perception of avant-garde works as inaccessible or high-brow, and emphasize how pop-art films such as Scorpio Rising could be used for educational purposes.

Another example of Sloan's approach to introducing provocative new works to public libraries and film-going audiences was What's Happening, a weekly series programmed at Donnell by Sloan and Ted Perry of the Museum of Modern Art. The series was started in 1972 by film curator John Hanhardt, who then entrusted it to Sloan and Perry following his promotion to head of the Whitney Museum film department. ${ }^{118}$ The programs for this series consisted of "social documentaries [...] not readily available" or programmed on television, which Sloan and Perry believed would offer "diverse issues and interpretive film reporting" to the public. ${ }^{119}$ One of the earliest iterations of programs by Sloan and Perry for this series occured on October 1, 1974, and included controversial documentaries on drug overdose (Methadone: An American

\footnotetext{
${ }^{115}$ Gordon Boyd, “400 at Linton View 'Underground' Films,” The Schenectady Gazette, March 12, 1968, n.p.

${ }^{116}$ Ibid., n.p.

${ }^{117}$ William J. Sloan, "Projections," Film Library Quarterly 7, 3/4 (1974), 3.

${ }^{118}$ S.M. Silverman, "Man Behind Quiet MOMA Success," The New York Post, December 30, 1977, 27.

${ }^{119}$ Lillian Gerard, "Your Program and the News Media," Film Library Quarterly, 3, 4 (1974), 80.
} 
Way of Dealing, dir. Julia Reichert \& James Klein, 1974), Native American rights (Cree Hunters of Mistassini, dir. Boyce Richardson, 1974), filmmaker Amalie R. Rothschild (Nana, Mom, and Me, dir. Amalie R. Rothschild, 1974), and industrial pollution (Earth People, dir. James Rich) were screened. ${ }^{120}$ These films, and every film to be programmed afterwards, would reflect Sloan's and Perry's philosophy that film librarians were responsible for "showing films of interest to special or small groups" outside of "mass audience tastes," and ensuring that public library film programming changed as "public attitudes and needs [changed]."121

This series was a unique collaboration between two public institutions with film collections that differed in their approach to public access, as well as the contents of their respective collections. Sloan touched upon this unusual relationship in a 1977 letter to Edwin Holmgren, Branch Library System Director for The New York Public Library, requesting authorized leave to present his speech "The Film Libraries of The New York Public Library and the Museum of Modern Art - A Comparison," at an ALA conference in Detroit later that year:

I have been asked to speak on [...] on [What's Happening] [...] Although the MOMA's film library is generally considered to be the most important film collection in the U.S., [NYPL's] collection now far surpasses them in [...] public affairs documentaries, and children's cinema, so that I feel that in comparison of the two collections we will emerge as an unequalled community resource. ${ }^{122}$

The film programs for the What's Happening series were perhaps the clearest indication of what films Sloan prioritized as permanent additions to The New York Public Library film collection. In his 1977 New York Post article on the series, journalist S. M. Silverman observed how Sloan

\footnotetext{
${ }^{120}$ Gerard, "Your Program and the News Media," 80.

${ }^{121}$ William J. Sloan, "Projections," Film Library Quarterly 8, 2 (1975), 4.

${ }^{122}$ William J. Sloan, William J. Sloan to Edwin Holmgren, April 29, 1977, letter, William J. Sloan Documents, New York Public Library, New York, n.p.
} 
did not weigh films "in regard to their method of presentation nor perspective," but rather their “content," focusing his attention upon "any series dealing with contemporary political and social issues [...] bound to spark controversy." 123 As Sloan explained, "There was tremendous pressure not to buy [Methadone: An American Way of Dealing], [...] so, of course, I had to buy it. It concerned the [use] of methadone as a treatment for heroin addicts [...] and the medical profession demanded equal time." 124

Sloan's work with the Film Library Information Council also allowed him to organize many international workshops and seminars promoting similarly provocative works, or emerging media formats. FLIC notably partnered with the National Film Board of Canada throughout the 1970s, presenting a Cinema Canada workshop at the Film Board's production headquarters in Montreal from the 22nd to the 25th of September in 1971. The workshop, jointly coordinated by Sloan, Colin Neale of the Film Board, and Esme Dick of the Educational Film Library Association, was described as, "An unusual workshop on Canada's contribution to the cultural/educational film," covering "the whole spectrum of cinematic achievement [...] from current experiments in avant-garde and documentary to early landmark films." ${ }^{125}$ Activities included screenings, Film Board production tours, and lectures by leading Canadian filmmakers, such as Alan King, Ryan Larkin, and Norman McLaren. ${ }^{126}$ Frame-By-Frame, a two-day workshop on Film Board animation films (coordinated by Sloan, Dr. Thelma Schenkel from Baruch College, and Louise Beaudet from Cinémathèque québécoise) was soon to follow in

\footnotetext{
${ }^{123}$ Silverman, "Man Behind Quiet MOMA Success," 27.

${ }^{124}$ Idib., 27.

${ }^{125}$ The Film Library Information Council, “Cinema Canada,” press release, 1970, n.p.

${ }^{126}$ Ibid., n.p.
} 
1978, with a second iteration in $1979 .{ }^{127}$ A press release for the 1979 workshop stated that it was "a rare opportunity to meet filmmakers, such as Al Jarnow, Kathy Rose, and Maureen Selwood, see films, and discover rare titles that are quite often unavailable through regular distribution channels." ${ }^{128}$ For Sloan, it was a chance to bring international awareness to the Film Board, a production body from his native country that he greatly admired and from which he regularly programmed works from at Donnell. Indeed, commenting on Cinema Canada in Film Library Quarterly, Sloan remarked, "Canadian films form an essential part of our library collections. The films, the projects, the ideas, coming out Canada are pointing the way for exciting future developments $[. .$.$] which can and should play a significant role in public library service in$ Canada and the United States." ${ }^{129}$

Sloan and the Film Library Information Council also programmed a series of seminars on video and its significance to public library collections. An early seminar of note was Videography I, held on November 10, 1972 and described as "a short course in the applications of tape and Cable television." ${ }^{130}$ Attendees were invited to test a $1 / 2$ " Portapak, view video art in "four simultaneous mini-viewing centers," and participate in a Q\&A session with Sloan, Russell Connor of the New York State Council on the Arts, and then director of the Alternate Media Center at New York University, George C. Stoney. ${ }^{131}$ This seminar would be followed by the more comprehensive Video Art as a Library Medium, which was held at Donnell on March 25, 1977 and featured demonstrations of recording and playback equipment, electronic production

\footnotetext{
${ }^{127}$ The Film Library Information Council, "Frame by Frame," press release, 1978, n.p.

${ }^{128}$ The Film Library Information Council, "Frame by Frame II," press release, 1979, n.p.

${ }^{129}$ William J. Sloan, "Projections," Film Library Quarterly 4, 4, 1971, 3.

${ }^{130}$ The Film Library Information Council, "Videography II," press release, 1972, n.p.

${ }^{131}$ Ibid., n.p.
} 
methods, and a video exhibition panel with Carlotta Schoolman of The Kitchen for Video and Music, Lillian Gerard of the Museum of Modern Art, John Hanhardt of the Whitney Museum of American Art, Phillip Mallory Jones of Ithaca Video Projects, and Sloan acting as moderator. ${ }^{132}$

On June 2, 1979, less than a year before his resignation from The New York Public Library, Sloan and the Film Library Council held another influential seminar on video entitled, Video is Art/Video is Documentary. Held at the Sheraton Centre Hotel in New York, video artists Wendy Clarke, Kit Fitzgerald, John Sanborn, and Ingrid Wiegand screened their work and participated in a discussion about "the various forms the video art movement [was] taking" in the late 1970s.

A press release explained that the emphasis of the seminar was on "original video-works produced and distributed as video," and the development of "video services" and "future possibilities of video as a library medium," the last two were key elements of large-scale video projects Sloan had just completed at The New York Public Library. ${ }^{133}$

\section{3 "Video Art as a Library Medium"}

In a 1971 issue of Film Library Quarterly, Sloan outlined what he thought should be the ongoing responsibility of media librarians:

Librarians should experiment with [...] newer media. In fact FLIC has been at the forefront in promoting projects with the new formats [...] The potential of these and other systems that will be entering the market [is] immense, and if public libraries wish to remain in the forefront they will have to be aware of and willing to experiment with these formats. $^{134}$

\footnotetext{
132 The Film Library Information Council, "Video Art as a Library Medium,” press release, 1977, n.p.

${ }^{133}$ The Film Library Information Council. "Video Art/Video is Documentary," press release, 1979, n.p.

${ }^{134}$ William J. Sloan, "Projections,” Film Library Quarterly 4, 3 (1971), 2.
} 
Improved technology and accessibility were key factors in what media Sloan chose to collect at The New York Public Library, even when he perceived a decrease in their aesthetic or creative quality. While Sloan was an early adopter of video cassettes in public library audio-visual departments, he viewed video as a dubious, yet necessary means to increase public access to moving image media, telling journalist Mary Wade Burnside in 1987, "[Video] changed the industry a whole lot. In some instances, video improved film libraries by increasing interest, but in some places, it's gone downhill." ${ }^{135}$ Sloan was less cryptic in his 1980 American Library Association annual report for the Circulating Film Library at the Museum of Modern Art, explaining that what had "[inhibited] real growth" of video was "a lack of standardization among video technologies, and [...] good educational programs." ${ }^{136}$

Nevertheless, Sloan promoted the collection of video cassettes and playback equipment at The New York Public Library up until his resignation in 1980, recognizing its importance as uniquely accessible format. Just as he had with $16 \mathrm{~mm}$ film, Sloan endeavoured to make provocative video works available to the public, which he saw as "valuable cultural documents, that otherwise [were] not [seen] by many who would benefit from their use." ${ }^{137}$ Sloan was inspired by video artists who despite "[varying] widely in [ability], artistic sensibility, and technical skill," seemed to "share a common commitment to promoting social reform." 138 Moreover, the low cost of video technology and desire of video artists to cooperate with public libraries inspired Sloan to transform The New York Public Library into a community media

\footnotetext{
${ }^{135}$ Mary Wade Burnside, "Librarian Promotes Obscure Films," The Charlotte Gazette, Oct. 2, 1987, n.p.

${ }^{136}$ William J. Sloan, "Films: ALA Yearbook," report, 1980, William J. Sloan Documents, New York Public Library, New York, 1.

${ }^{137}$ William J. Sloan, “Nonprint Proposals Created by the Nonprint Media Committee," n.d., William J. Sloan Documents, New York Public Library, New York, 4.

${ }^{138}$ William J. Sloan, "Projections: The Avant Garde of Television,” Film Library Quarterly 4, 1 (1971), 2.
} 
center where artists and patrons could view video art, discuss issues of public access, and even produce their own videos through workshops and with the help of media specialists on staff. ${ }^{139}$ This was the impetus leading to the construction of the Video/Film Study Center.

There is every indication that Sloan's foresight to promote and collect video at Donnell not only ushered The New York Public Library into a new era of communication, but also allowed it to flourish as a media center for decades to come. Deirdre Boyle of American Libraries reported in October of 1976 that "The New York Public Library, one of the many endangered libraries suffering from service and funding cutbacks," had been fortunate to receive a grant from the New York State Council on the Arts to construct the Video/Film Study Center. ${ }^{140}$ Earlier that year, Sloan had suggested to Don Walker, Coordinator of Adult Services, that The New York Public Library vie for such a grant in order to fund the Video/Film Study Center, and receive regularized funding in the same manner as the Metropolitan Museum of Art. Sloan explained that in order to accomplish this, The New York Public Library "would have to demonstrate to the Council that we are delivering an essential service" or "important community service."141 After successfully illustrating the importance of the center with a small and experimental collection of videotapes, the grant was received later that April, allowing The New York Public Library to build "New York State's largest video collection accessible to the general public." ${ }^{142}$ The immediate success of the Video/Film Study Center allowed The New York

\footnotetext{
${ }^{139}$ Sloan, "Projections: The Avant Garde of Television," 2.

${ }^{140}$ Boyle, "Video: What Librarians Do with a Recycle Medium," 584.

${ }^{141}$ William J. Sloan, William J. Sloan to Don Walker, January 3, 1976, letter, William J. Sloan Documents, New York Public Library, New York, n.p.

142 Boyle, "Video: What Librarians Do with a Recycle Medium," 584.
} 
Public Library to increase the Film Library materials budget to $\$ 10,000$ for purchasing video art tapes and "another $\$ 5,000$ for video informations tapes" in $1977 .{ }^{143}$

A notable purchase included The Autobiography of Miss Jane Dubois (1977), a video work by Alan Hertzberg, artist and faculty member of the Media Studies Program at The New School for Social Research. The purchase was facilitated by Sloan and Mary Feldstein, media specialist and director of the Video/Film Study Center. ${ }^{144}$ As reported in MediaLog, Hertzberg was present at Donnell on October 12, 1978 to exhibit and discuss a shortened version of this "video autobiography." 145 Structured as an extended video interview with Jane Dubois, a struggling 32-year old black woman in New York City, Hertzberg described the piece as free from the constraints of "the photographic medium," which only allowed for communication “[through] images frozen in time." ${ }^{146}$ Hertzberg explained that the flexibility of the video format "[lent] itself to various viewing situations," and therefore, the piece, edited into twelve chapters, could be exhibited "by having each chapter on a separate tape loop so the viewers can pick and choose their own sequence; walking in and out of a person's life." 147

\subsection{The Teen-Age Video Workshop}

The Video/Film Study Center would not have been possible without the earliest video project for which Sloan was responsible for at The New York Public Library: the Teen-Age

\footnotetext{
${ }^{143}$ Deirdre Boyle, "Video Art: Not for Visionaries Only," American Libraries 8, 6 (1977), 349.

${ }^{144}$ Victor Ancona, "The Doings at Donnell: Collecting Artists' Tapes for Public Use.” Videography, October 1977, 83.

145 "Events," MediaLog 4, 1 (1978), 3.

146 "Premier of Video Autobiography," MediaLog 2, 6 (1977), n.p.

${ }^{147}$ Ibid., n.p.
} 
Videotape Workshop. The workshop began as a package proposal to implement video technology into the Branch Libraries of The New York Public Library. Initially described as a workshop involving "teenagers in 15-20 branches [...] using video tape to explore their neighbourhoods," the proposal did not receive funding from the New York State Council on the Arts; however, Scott Morris, a then 21-year old filmmaker whose work had been shown with the support of The New York Public Library Office of Young Adult Services, volunteered the use of a Sony Rover Portapak for the workshop through the New York State Council on the Art's Media Equipment Resource Center (MERC). ${ }^{148}$ Morris’s support, in addition to \$500 subsequently donated by the New York State Council on the Arts through the cooperation of the Young Filmmakers Foundation and The New York Public Library administration, were what allowed the first ten-week video workshop to begin in October 1971. In a letter to Michael Ayres, chief of Public Relations for Ampex Corporation, applying for corporate sponsorship for the workshop, Sloan described the purpose of the project as follows:

The basic purpose of the project is to demonstrate that public libraries present an ideal forum for [Video Tape Recorder] projects on public issues for programming in the library and for presentation on cable television [...] We will be working out of the library with a small group of young people over ten Saturdays beginning October 30, in areas of documentary, drama, and experimental work. ${ }^{149}$

The first series in this workshop focused its efforts on exploring the Nathan Strauss Young Adult Library's community, and documenting the National Peace Action Coalition's Peace March on November 6th, 1971. As explained by Young Adult Librarian Mary A Brown, who was in attendance, press passes for the Vietnam Veteran's contingent were obtained by Sloan and

\footnotetext{
${ }^{148}$ William J. Sloan, "History of Video Service in The New York Public Library, Branch Libraries," report, April 8, 1977, William J. Sloan Documents, New York Public Library, New York, n.p.

${ }^{149}$ William J. Sloan, William J. Sloan to Michael Ayres, October 26, 1971, letter, William J. Sloan Documents, New York Public Library, New York, n.p.
} 
Assistant Film Librarian Emma Cohn, where the group interviewed "veterans of World War I, Vietnam Veterans Against the War, [...] the Ethical Culture Society, librarians marching with Local 1930, New York Public Library Guild, as well as construction workers watching from their worksites." ${ }^{150}$ The content and use of these recordings were later discussed by the group at the editing facilities of MERC, with technical and creative weaknesses being identified for future workshops. The 25 hours of tape collected from this workshop were to become what Videography columnist Victor Ancona referred to as "the nucleus of the videotape collection" at The New York Public Library, and allowed Sloan "to [expand] the concept of video as a library medium," which in turn let to the Videography I seminar sponsored by Film Library Information Council. ${ }^{151}$

\footnotetext{
${ }^{150}$ Mary A. Brown, “Teen-Age Videotape Workshop," Film Library Quarterly 5, 3, 1972, 16.

${ }^{151}$ Ancona, "The Doings at Donnell," 81.
} 


\section{Conclusion}

The aim of this thesis was to bring greater attention to William J. Sloan's innovative mindset and contributions as the first Supervising Film Librarian for The New York Public Library from 1958 to 1980, as well as an educator and film programmer in New York City. To achieve this objective, it was necessary to rely on primary sources, i.e., Sloan's documents contained in the nine boxes donated to NYPL. However, the research I have completed is but a small part of the work remaining to be done on Sloan, in particular his presence in the New York film community following his resignation from The New York Public Library and his subsequent work at the Museum of Modern Art up until the time of his passing in 2017.

The clear limitations of this project are what I hope will inspire and guide future researchers: namely, to fill in the gaps of Sloan's fruitful film programming career, and close relationships with filmmakers he championed both at The New York Public Library and the Museum of Modern Art. These gaps exist in my thesis due to time constraints and also the circumstances of approaching these documents for the very first time. Being the first scholar to explore this material, inevitably subjective decisions were made on my part, specifically in how the documents supported my thesis and what elements of Sloan's life and career to focus on. Having begun what is a much larger project, I wish for future researchers to use this thesis as a stepping stone to exploring Sloan's prolific career in even greater detail. 


\section{Appendix A: William J. Sloan's Syllabi}

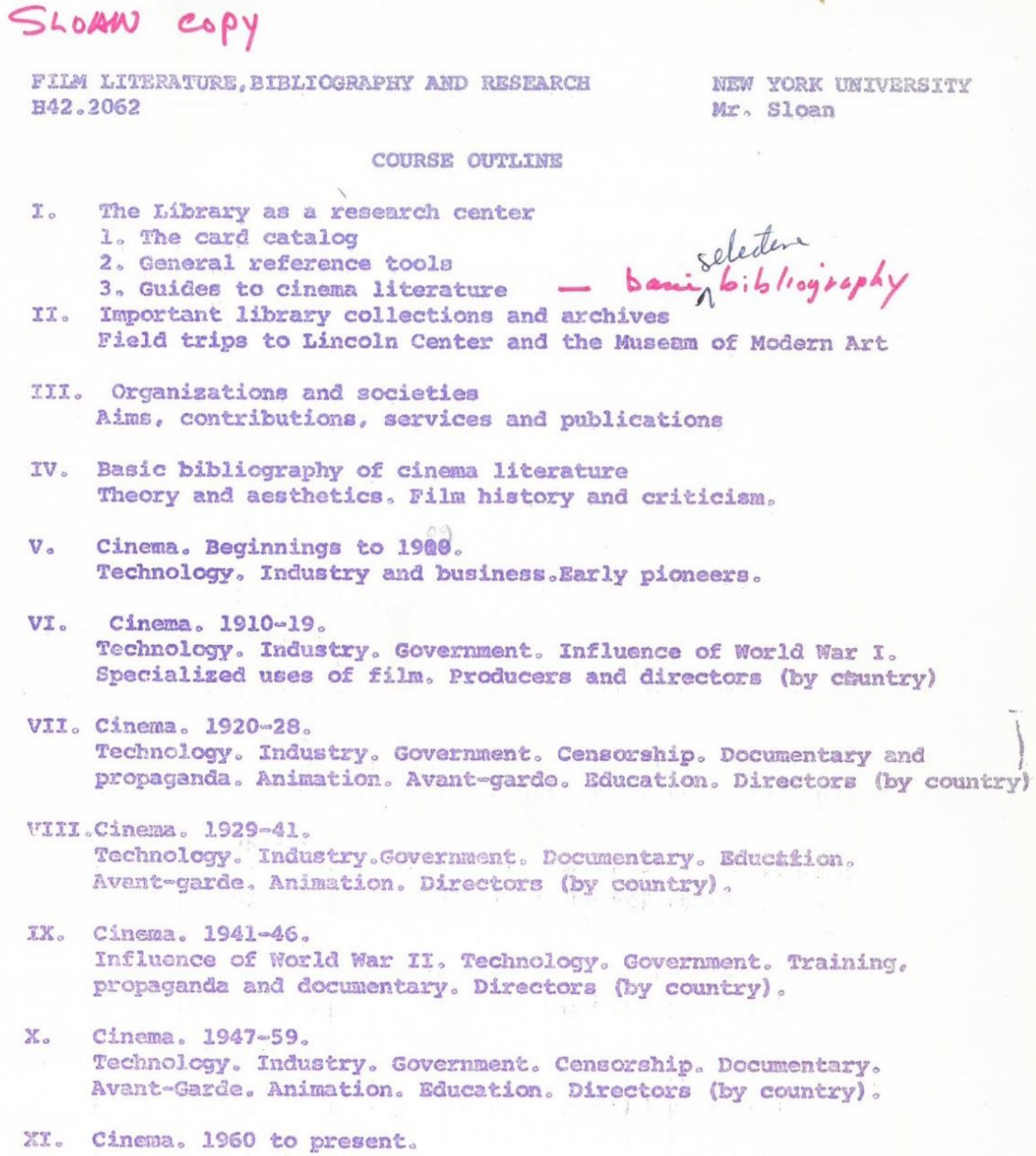




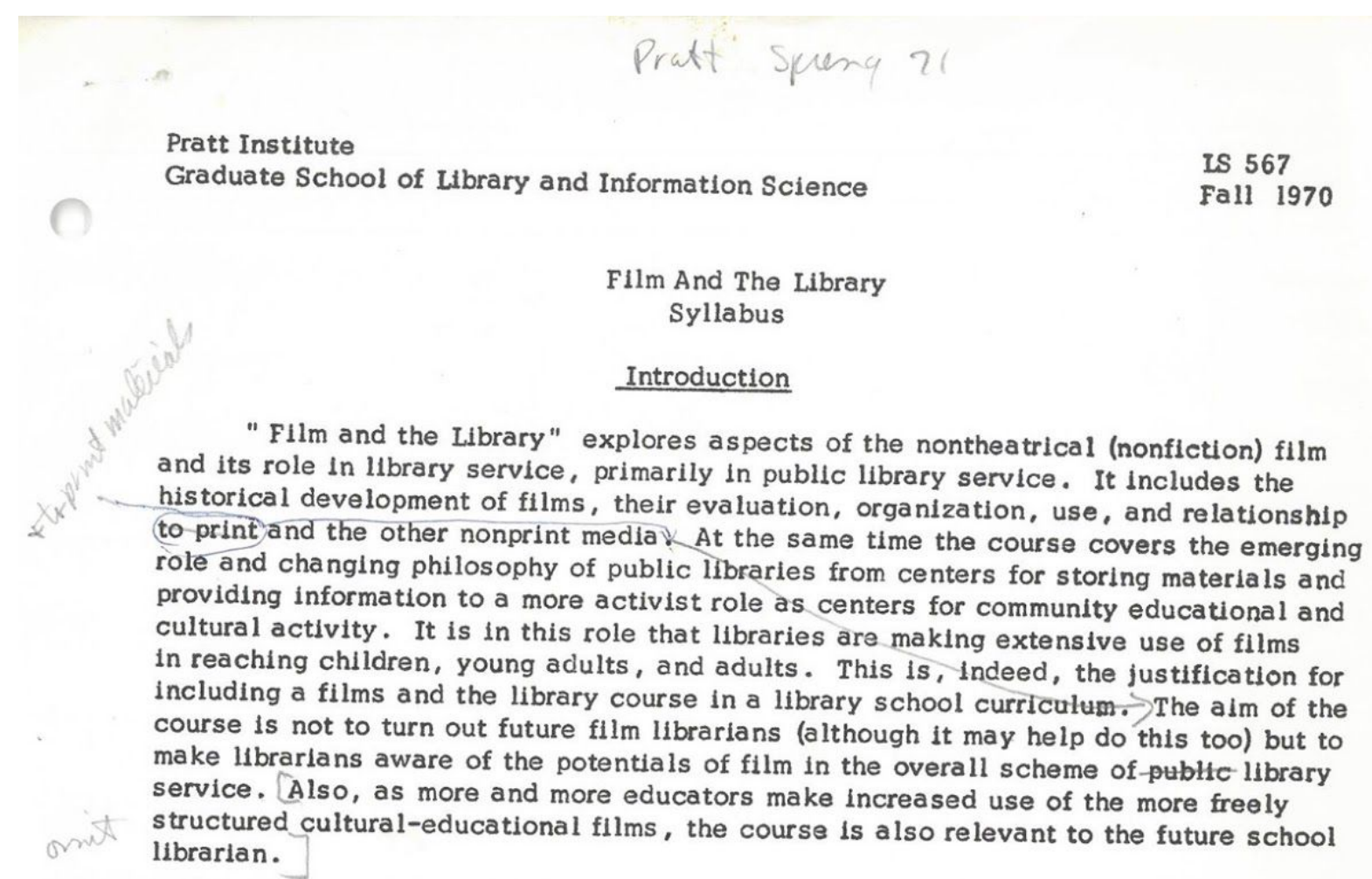

Included in the course is an examination of the new technolgies in the field such as cartridge television sytems, and super $8 \mathrm{~mm}$ sound films. Assignments consisist of readings, film screenlngs, and written reports, and a witle ted

Class 1 Sept. 21. Purpose of the cburse. Assignments and tests. Beginnings of the documentary. Beginnings of films in libraries. Fllm: Primary.

Class 2 Sept. 28. Film terms. Cinema verite and current documentary style. Beginnings of cinema: Lumiere, Melies, Edison, Porter, D.W. Griffith. Fllms: Melies reel; Great Train Robbery; Great Director (Griffith).

Class 3 Oct.5 Function and programing of documentaries in libraries. The social documentary tradition. Role of the U.S. and Canadian governments in film making. Film: The River (Lorentz)

Class 4 Oct. 12. Basic books on the cinema. Influence of McLuhan. Two roles of the Film Board of Canada: Challenge for Change; Norman McLaren. Films: Pas de Deux; Charlie Squash Comes to Town; Ballad of the Crowfoot.

Class 5 Oct. 19 Nontheatrical Film: Sources of Production, Distribution, and Exhibition. Recreating the past through film. Film: Battle of Culloden.

Class 6 Oct. 26 New media in libraries. Cassette (cartridge) television systems and implications for libraries. Libraries and youth. Film: One Step Away. 
Class 7 Nov. 2 The $8 \mathrm{~mm}$ films: application and potentials. Film of Robert Flaherty. Film: Man of Aran.

Class 8 Nov. 9 Basic reference books. Proverty problems and programs and the library. Film as anthropological document. Film: Holy Ghost People.

Class 9 Nov. 16 Reference books. Role of the library and race relation films, and films on the black experience. Films: A Time for Burning; the Black Panthers.

Class 10 Nov.23 Mid-Term test.

Class 11. Nov.30 Film Library Administration: circulation; technical processes; reference and reader guidance; care and storage; clerical functions. The animation film: technique; potentials in programs. Films: Hole; Symmetry; Sand; Toy That Grew Up.

Class 12 Dec.7 Role of the library and film art, the avant garde; the underground. Problems of censorship. Films: Bilabong; Blazes; Moon 69; A Movie; Lines Vertical.

Class 13 Dec.14 Pamplet files. Periodicals. Cataloging: the book and card catalog; subject headings for films; LC cards. Children's Cinema. Films: Steadfast Tin Soldier; Drummer Hoff; White Mane.

Class 14. Dec.21 Professional film organizations and publications. Children's cinema continued. Films: Housemoving; Fiddle-De-Dee; Anansi the Spider.

Class 15. Jan.4 Major film sources. Films and the Narcotics problem. Patterns of state film service in the U.S. Films: Speed Scene; The Trip Back.

Class 16 Jan.ll Job opportunities in film and film-related libraries. Film making projects with youth and in poverty projects as a tool for social change. Films:

Now that the Buffalo Is Gone; Menagerie; La Jetee. 


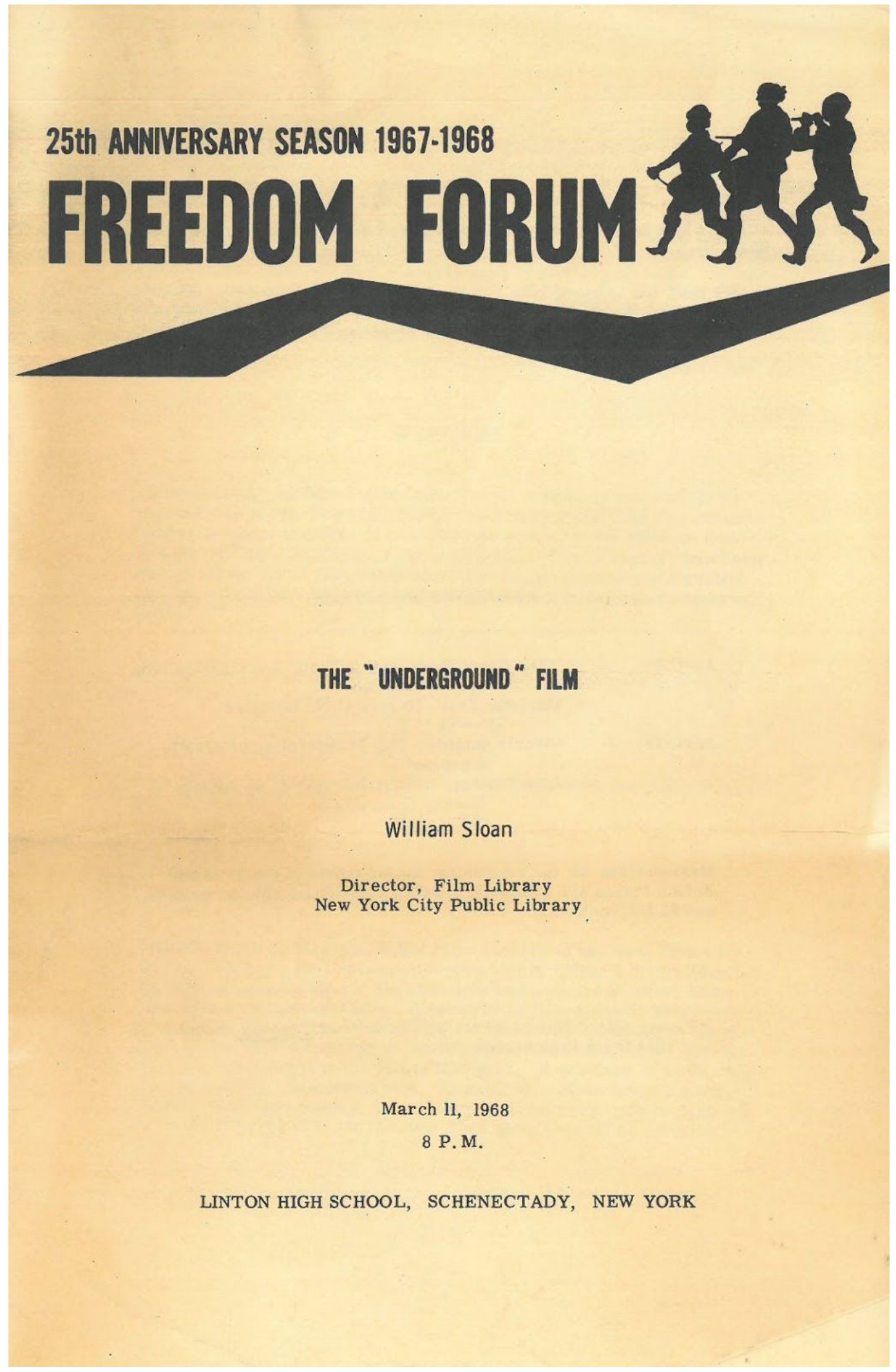




\section{Scorpio Rising}

Kenneth Anger's "'Scorpio Rising" has been described as the "jewel of the underground cinen.a." A psychologically penetrating and poetic docum entary about the Hell's Angels-type of motorcycle cult, "Scorpio Rising," has won many awards including first prize at the 1966 Filn. Festival at Evian, France. Anger is considered one of several filmmakers who has had a profound influence on the underground film.

\section{Breathdeath}

"Breathdeath" by Stan Vanderbeek was the winner of the Bell Telephone Prize at the Third International Experimental Film Competition held in Belgium in 1964. It has also won prizes at the Midwest and Ann Arbor Film. Festivals in the same year. "Breathdeath" has been described as "... a film experiment that deals with the photo reality and the surrealism of life... a black comedy, a fantasy that mocks at death..."

$$
12-12-42
$$

"12-12-42" by Bernard Stone has been called a very funny and powerful anti-war film.

\section{William Sloan}

William Sloan is Director of the Film Library of the New York City Public Library. He is also editor-in-chief of "Film Library Quarterly" and is well-known for his criticism and articles on short films, including underground films. A lecturer in film study at Pratt Institute, he writes a monthly column for "Media and Methods" magazine and will become a nember of the faculty of the New York University Cinema Department in the fall of this year. A graduate of Mount Allison University, New Brunswick, Canada, Mr. Sloan holds a master's degree in library science from Columbia University. He is currently a lecturer on the film for the New York State Council on the Arts. 


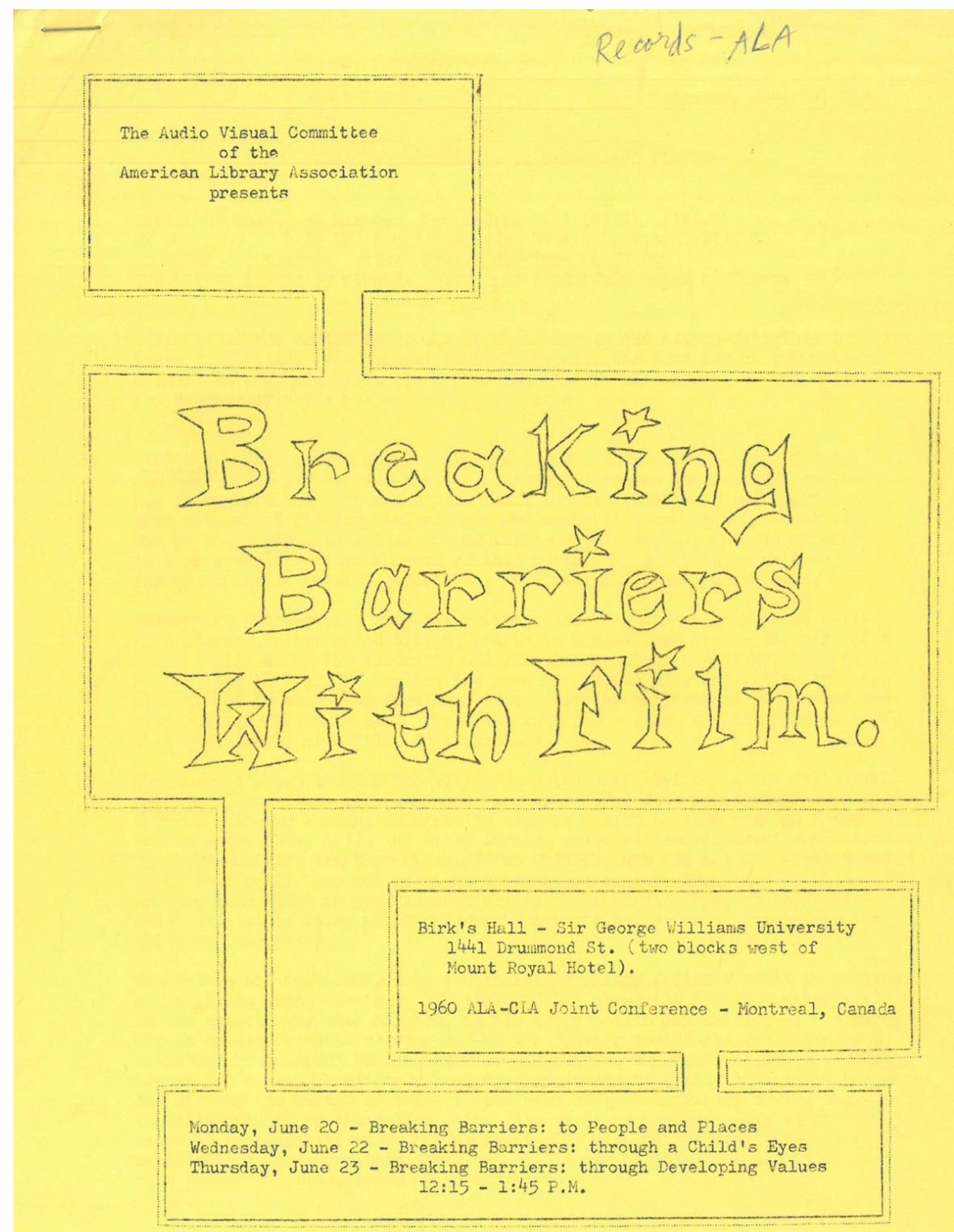


FAMTIY OF GHANA 30 minutes b/w McGraw-Hill (NFEC) $\$ 125.00$ MI OWN YAFD TO PLAY IN 6 minutes $\mathrm{k} / \mathrm{w}$ Edwara Harrison $\$ 110.00$ MOONBTRD 10 minutes color Eâward Harrison $\$ 1.20 .00$ THE LIVING STONIE 33 minutes color National Film Board of Canada $\$ 260.00$

There is a wide variation in the kinds of people and places described in these four films. For general-audience appeal, the four can be shown together, as they are here. Each film can also be used alone, as the basis for a program on its respective subject area.

FAMTLY OF GIATA is the story of the people who live on the coast of Ghana and make their living from the sea. Conflict betiveen the olu ways and the new is represented by a father who holds to the traditional but unproductive methods of fishing, and his son who wants to modernize these methods. One of the truly outstanding documentaries on Africa, the fijm is effective in a program on various a spects of this continent, on Dominion nations, on the relationship between generations in a family, on ancient customs.

Perceptive photography, skillful editing, and a candid soundtrack of children playing, singing and talking create an unusual and moving document of a child's life among the tenements and cluttered vacant lots of ilew York City. MY OWN YARD TO PLAY IN inplies the need for better play facilities in large cities, but it also denonstrates the ingenuity of children at play under the most adverse circumstances. These implications suggest the infinite uses of this excellently made film, in programing.

The ingeruity and imagination of children are more obvious in the delightful MONBIRD. Two young boys sneak out of their house late at night armed with a rope, bait and a cage, in order to capture a bird to take home as a pet. Artist John Hubley tells the story through colorful semi-abstract animation; on the soundtrack are the voices of two children who for all the world sound as if they really are out at night hunting the elusive "Moonbird." This amusing film might be used as contrast to the foregoing one, or in combination with other films about children's activities, or on a program for the children themselves.

Two things are most admired by the Eskimo of Baffin Island - skill in hunting and skili in stone carving. THE I.IVING STONE shows the Eskimo hunting seal in the age-old way with harpoon, in his daily battle for existence. It shows him in quieter moments carving out of the "living stone" the mall images he believes are inherent in the material and possess supernatural power to aid hin in the hunt. Sensitively photographed scenes of family life which reveal the dignity and warmth of these people make this an unusually moving and beautiful record of their life. The film might be used not only as program material on social customs, but it might also exemplify a consideration of developing values, for this shows not only a way of life, but the attitudes of a people which are bound up with that way. 


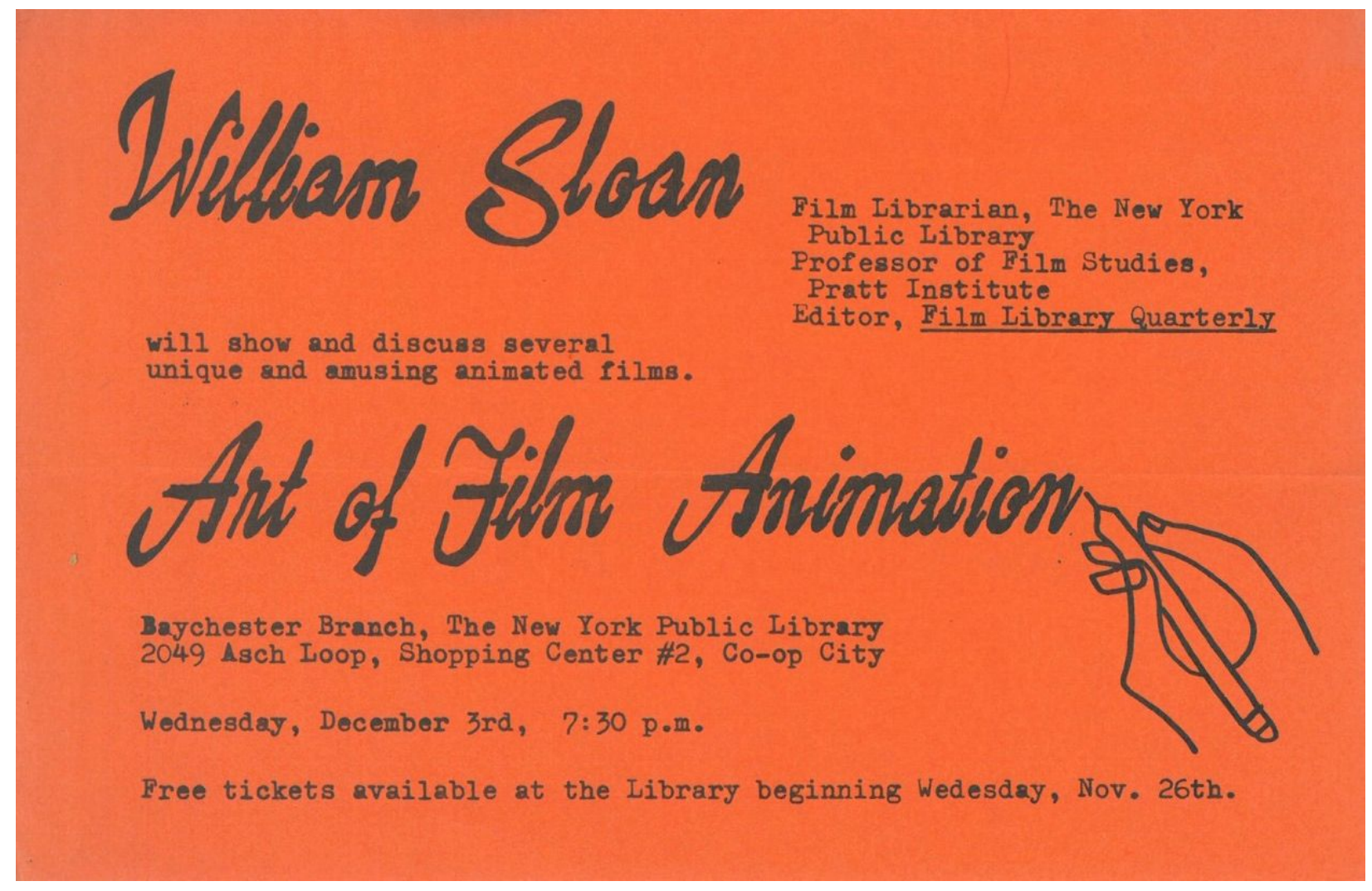




\section{Appendix C: Film Programs Organized by Film Library Information Council (FLIC)}

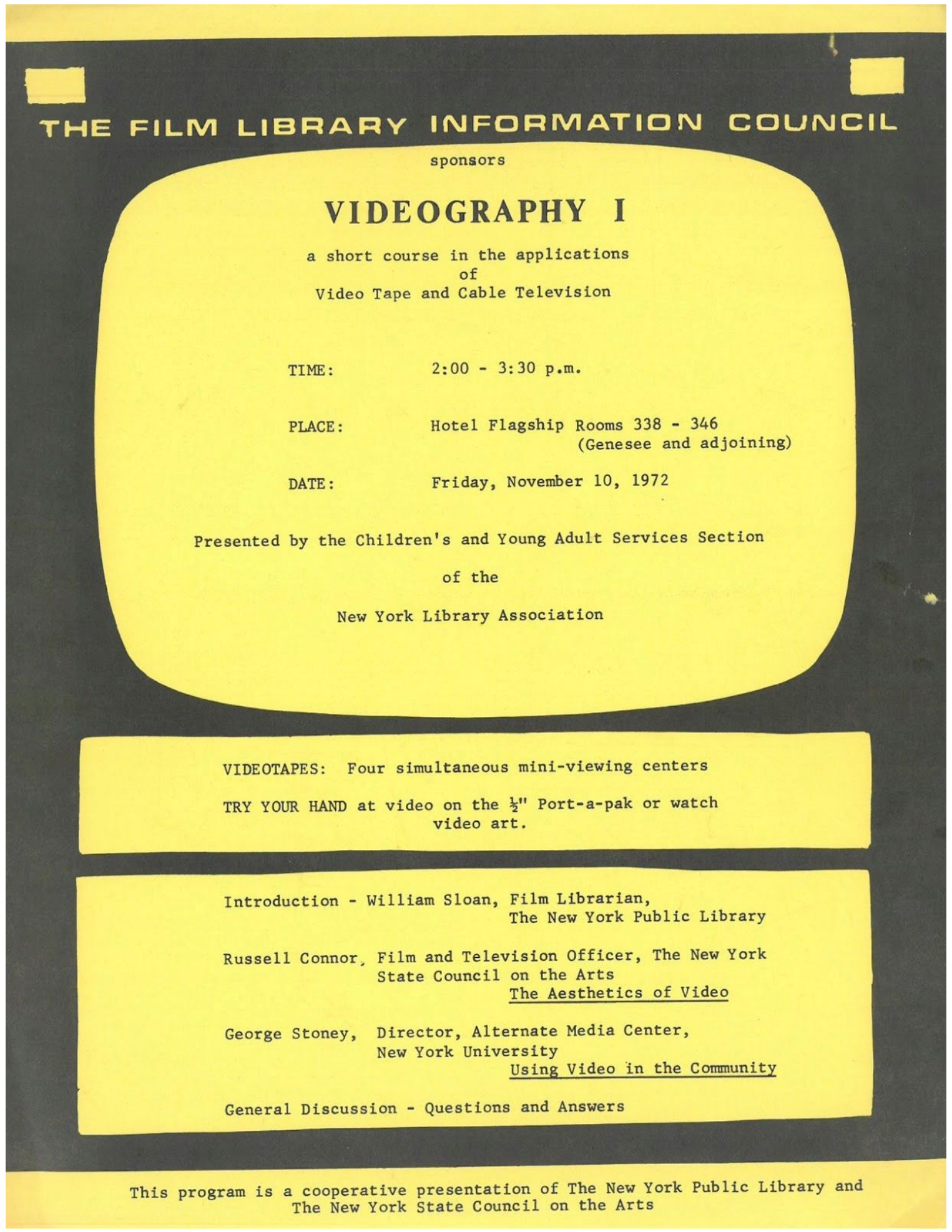




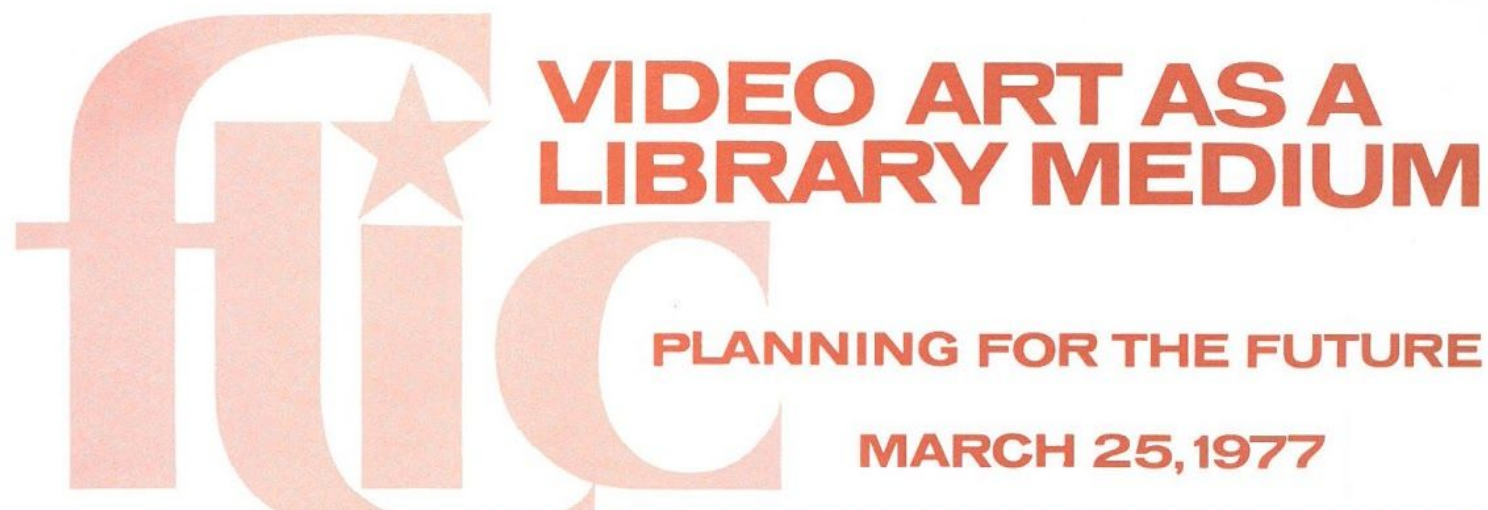

A day-long seminar presented by the Film Library Information Council in cooperation with the New York State Council on the Arts and the Video/Film Study Center of The New York Public Library.

To be held in New York City in the Auditorium of the Donnell Library Center at 20 West 53rd Street

9:30-10:00 a.m. REGISTRATION.

10:00-10:15 a.m. INTRODUCTIONS: Philip Levering, Chairman of the Board, Film Library Information Council. William Sloan, Film Librarian, The New York Public Library.

Peter Bradley, Director of Programs, Film, TV Media and Literature, New York State Council on the Arts.

10:15-10:45 a.m. Russell Connor, Executive Director, Cable Arts Foundation. The Roots of Video Art.

10:45-11:30 a.m. John Riley, Director, Global Village. Demonstration of production and playback equipment and their potential in libraries.

11:30-12:15 p.m. Louise and Bill Etra

Computer Video Art. Electronic manipulation of imagery.

1:30- 3:00 p.m. Hermine Freed The Art of Video.

3:00- 4:30 p.m. VIDEO EXHIBITION. Planning programs and publicity. Speaker: Carlotta Schoolman, Video Director, The Kitchen for Video and Music.

Panel: Lillian Gerard, Special Projects Coordinator, Museum of Modern Art. John Hanhardt, Curator, Film and Video, Whitney Museum of American Art. Philip Mallory Jones, Director, Ithaca Video Projects. William Sloan, Moderator.

4:30-5:00 p.m. Showing of Works by New York State Video Artists. Presented by Mary Feldstein, Media Specialist, The New York Public Library.

5:00- 7:00 p.m. Dutch Treat Cocktail Party at "Top of the Sixes,"

666 Fifth Avenue, next door to the Donnell Library.

REGISTRATION for this seminar is free, but since seating is limited, it is necessary to register in advance in order to hold a seat. Send your application to.

Film Library Information Council

Box 348, Radio City Station, New York, N.Y. 10019

Name

Library

Address

City

State Zip

THIS CONFERENCE IS MADE POSSIBLE BY THE SUPPORT OF THE NEW YORK STATE COUNCIL ON THE ARTS 


\section{Appendix D: Information on Film Programs Organized by William J. Sloan $\underline{152}$}

\begin{tabular}{l|l}
\hline Program Title & American Library Association: Outstanding Films of the Past Year \\
\hline Date(s) & 07/11/66, 07/12/66, 07/13/66, 07/14/66, 07/15/66 \\
& The Reality of Karel Appel (Jan Vrijman, 1962), White Throat [unclear], \\
& Clay [unclear], The String Bean (Edmond Séchan, 1965), Whistle for \\
Willie (Mal Wittman, 1965), The Detached Americans (Philadelphia Gas \\
Works, 1965), Antonio Gaudi (Ira H. Latour, 1964), A Scrap of Paper and \\
a Piece of String (John Korty, 1964), Critical Decades (George C. Stoney, \\
1965), Boiled Eggs (Marc Andrieux, 1963), Israel [unclear] / Days of \\
Dylan Thomas (Graeme Ferguson, 1965), Canon [unclear], Seven Authors \\
in Search of a Reader (Franz Weisz, 1966), The Stonecutter (Gerald \\
McDermott, 1960), Moto Gaz (Karl Urbanski, 1965), You Don't Back \\
Down (Don Owen, 1965) \\
Films Screened & "Audio Visual Committee, American Library Association presents a Series \\
of Film Programs." & - -- \\
Program Notes & --
\end{tabular}

\begin{tabular}{l|l}
\hline Program Title & Freedom Forum: The "Underground" Film \\
\hline Date & 03/11/68 \\
\hline Films Screened & $\begin{array}{l}\text { Scorpio Rising (Kenneth Anger, 1963), Breathdeath (Stan Vanderbeek, } \\
\text { 1963), 12-12-42 (Bernard Stone, 1967) }\end{array}$ \\
\hline "25th Anniversary Season 1967-1968: Freedom Forum presents an \\
Experiment in New Art Forms -- Underground Films"; "A discussion of \\
these films and their relation to the Underground Film Movement by \\
WILLIAM SLOAN, Director of the New York Public Library Film \\
Library, Editor of "Film Library Quarterly," and outstanding lecturer, \\
author, and film critic."
\end{tabular}

\footnotetext{
${ }^{152}$ All programming information contained in this section was sourced from monthly program reports for Donnell, which were cross-referenced with program leaflets and Sloan's personal correspondence to confirm film and program titles.
} 


\begin{tabular}{|c|c|}
\hline Program Title & Evening Films \\
\hline Date & $10 / 23 / 68$ \\
\hline Films Screened & $\begin{array}{l}\text { Road to Santiago: France (Mary Kirby, 1967), Road to Santiago: Spain } \\
\text { (Mary Kirby, 1967) }\end{array}$ \\
\hline Notes & $\begin{array}{l}\text { American premiere screening: "Introductory remarks by William J. Sloan, } \\
\text { film librarian." }\end{array}$ \\
\hline Venue & Donnell Media Center, 20 W 53rd St, New York, NY \\
\hline Attendance & -- \\
\hline Program Title & Noon Films \\
\hline Date & $01 / 09 / 69$ \\
\hline Films Screened & $\begin{array}{l}\text { Symmetry (Phillip Stapp, 1966), A Day With Timmy Page (David Hoffman, } \\
\text { 1969), Abel Gance (Kevin Brownlow, 1968), Yesterday and Tomorrow } \\
\text { [unclear], Cinder City Plus Six (unclear, 1966), The End (Christopher } \\
\text { Maclaine, 1953), The Photographer (Williard Van Dyke, 1948) }\end{array}$ \\
\hline Notes & $\begin{array}{l}\text { FILMS AT DONNELL - Ten Noon Hour Programs - Thursdays, Second } \\
\text { Series, January } 9 \text { - March 13, 1969, 12:00 - 2:00 p.m. - Admission free }\end{array}$ \\
\hline Venue & Donnell Media Center, 20 W 53rd St, New York, NY \\
\hline Attendance & -- \\
\hline Program Title & Noon Films \\
\hline Date & $01 / 23 / 69$ \\
\hline Films Screened & $\begin{array}{l}\text { The Ancient New World (Rosemarie O'Conner, 1964), African Village Life: } \\
\text { Bozo Daily Life (Hermann Schlenker, 1965), The Ancient Peruvian (Julien } \\
\text { Bryan, 1967), End of the Trail: The American Plains (Donald B. Hyatt, } \\
\text { 1967) }\end{array}$ \\
\hline Notes & $\begin{array}{l}\text { FILMS AT DONNELL - Ten Noon Hour Programs - Thursdays, Second } \\
\text { Series, January } 9 \text { - March 13, 1969, 12:00 - 2:00 p.m. - Admission free }\end{array}$ \\
\hline Venue & Donnell Media Center, 20 W 53rd St, New York, NY \\
\hline Attendance & -- \\
\hline
\end{tabular}




\begin{tabular}{l|l}
\hline Program Title & Noon Films \\
\hline Date & $01 / 30 / 69$ \\
& $\begin{array}{l}\text { Very Nice, Very Nice (Arthur Lipsett, 1961), Religion in Russia (Julien } \\
\text { Bryan, 1968), Mekong (John Armstrong, 1964, South East Asia Shell Film } \\
\text { Unit), Primary (Robert Drew, 1960) }\end{array}$ \\
\hline Films Screened & $\begin{array}{l}\text { FILMS AT DONNELL - Ten Noon Hour Programs - Thursdays, Second } \\
\text { Series, January 9 - March 13, 1969, 12:00 - 2:00 p.m. - Admission free }\end{array}$ \\
\hline Notes & Donnell Media Center, 20 W 53rd St, New York, NY \\
\hline Venue & -- \\
\hline Attendance & \\
\hline Program Title & Noon Films \\
\hline Date & 02/06/69 \\
That Rotten Tea Bag (Andy Gurian, 1964), L'Adolesence (Marin Karmitz, \\
Films Screened
\end{tabular}

\begin{tabular}{l|l}
\hline Program Title & Noon Films \\
Date & 02/20/69 \\
& $\begin{array}{l}\text { The Hat (John \& Faith Hubley, 1964), Smile (Serge Bourguigon, 1964), } \\
\text { Interview (Ernest Pintoff, 1960), Railway With Heart of Gold (Carson } \\
\text { Davidson, 1965), Nanook of the North (Robert Flaherty, 1922) }\end{array}$ \\
\hline Films Screened & $\begin{array}{l}\text { FILMS AT DONNELL - Ten Noon Hour Programs - Thursdays, Second } \\
\text { Series, January 9 - March 13, 1969, 12:00 - 2:00 p.m. - Admission free }\end{array}$ \\
\hline Vetes & Donnell Media Center, 20 W 53rd St, New York, NY \\
\hline Attendance & 235
\end{tabular}




\begin{tabular}{|c|c|}
\hline Program Title & Noon Films \\
\hline Date & $02 / 27 / 69$ \\
\hline Films Screened & $\begin{array}{l}\text { Highway [unclear], The Great Director [filmmaker unclear, 1967], Dream } \\
\text { of Wild Horses (Denys Colomb de Daunant, 1960), Days of Dylan Thomas } \\
\text { (Graeme Ferguson, 1965), An Occurence at Owl Creek Bridge (Robert } \\
\text { Enrico, 1961) }\end{array}$ \\
\hline Notes & $\begin{array}{l}\text { FILMS AT DONNELL - Ten Noon Hour Programs - Thursdays, Second } \\
\text { Series, January } 9 \text { - March 13, 1969, 12:00 - 2:00 p.m. - Admission free }\end{array}$ \\
\hline Venue & Donnell Media Center, 20 W 53rd St, New York, NY \\
\hline Attendance & 234 \\
\hline Program Title & Noon Films \\
\hline Date & $03 / 06 / 69$ \\
\hline Films Screened & $\begin{array}{l}\text { Uptown: Portrait of the South Bronx (Herbert Danska, 1965), For All My } \\
\text { Students (Bonnie Sheer Klein, 1967), My Own Yard to Play In (Phil Lerner, } \\
\text { 1959), Mural in Our Street (Dee Dee Halleck, 1965), Harlem Crusader } \\
\text { (National Broadcasting Company, 1966) }\end{array}$ \\
\hline Notes & $\begin{array}{l}\text { FILMS AT DONNELL - Ten Noon Hour Programs - Thursdays, Second } \\
\text { Series, January } 9 \text { - March 13, 1969, 12:00 - 2:00 p.m. - Admission free }\end{array}$ \\
\hline Venue & Donnell Media Center, 20 W 53rd St, New York, NY \\
\hline Attendance & 511 \\
\hline
\end{tabular}

Program Title
Date
Films Screened
Notes
Venue
Attendance

Noon Films

03/13/69

Game of War (Peter Watkins, 1965), 12-12-42 (Bernard Stone, 1967),

Culloden (Peter Watkins, 1964), Time Out of War (Denis Sanders, 1954)

FILMS AT DONNELL - Ten Noon Hour Programs - Thursdays, Second Series, January 9 - March 13, 1969, 12:00 - 2:00 p.m. - Admission free Donnell Media Center, 20 W 53rd St, New York, NY 511 


Program Title
Date
Films Screened
Notes
Venue
Attendance

Program Title
Date
Films Screened
Notes
Venue
Attendance

Program Title
Date(s)
Films Screened
Notes
Venue
Attendance

Evening Films (William Greaves)

$11 / 03 / 69$

Emergency Ward (1959), In the Company of Men (1969), First World Festival (1966)

"A filmmaker speaks on film making: WILLIAM GREAVES."

Donnell Media Center, 20 W 53rd St, New York, NY - Admission free 180

Evening Films

$03 / 18 / 70$

The Face: Piero Fornasetti (Herbert Kosower, 1967), MROFNOC (John Josef Sedelmaier, 1965), Opening Speech of Norman McLaren (Tom Daly, 1963), Empty Hand (Stephen F. Verona, 1968), The Chicken [Claude Berri, 1965], Help! My Snowman Is Burning Down (Carson Davidson, 1964), ERSATS [unclear], Pigs [unclear]

Supervised w/ Nadine Covert -- "HUMOR IN FILM"

Donnell Media Center, 20 W 53rd St, New York, NY

256

Black Study Film Workshop

06/05/70, 06/06/70

$-$

Supervised w/ Assistant Librarian, Nadine Covert

Donnell Media Center, 20 W 53rd St, New York, NY

303,169

Community Film Workshop

$06 / 17 / 70$

Supervised w/ Assistant Librarian, Nadine Covert - "THE COMMUNITY FILM WORKSHOP COUNCIL: it's role in the training and placement of minorities in motion pictures and television and how films are used to bridge the gap in communications between divergent groups. Meet the filmmakers now participating in the CFWC program and see and discuss their films with them."

Donnell Media Center, 20 W 53rd St, New York, NY

155 


\begin{tabular}{l|l}
\hline Program Title & Evening Films (Gary Conklin) \\
\hline Date(s) & $02 / 17 / 71$ \\
\hline Films Screened & Paul Bowles in the Land of the Jumblies (Gary Conklin, 1970) \\
\hline Supervised w/ Assistant Librarian, Nadine Covert - "The film's director, \\
Gary Conklin will introduce the film and afterwards will answer questions \\
Venue & Donnell Media Center, 20 W 53rd St, New York, NY \\
\hline Attendance & 87
\end{tabular}

\begin{tabular}{l|l} 
Program Title & Noon Films \\
\hline Date(s) & $05 / 27 / 71$ \\
& $\begin{array}{l}\text { Les mistons (François Truffaut, 1957), The String Bean (Edmond Séchan, } \\
\text { 1965), Al Stacey Hayes (Joel A. Levitch, 1970), Boy of Central America } \\
\text { (unclear), Bubby (Murray Kramer, 1969), Woo Who? May Wilson (Amalie }\end{array}$ \\
Films Screened & "Youthschild, 1970) \\
\hline Notes & Donnell Media Center, 20 W 53rd St, New York, NY \\
Venue & 222 \\
\hline Attendance &
\end{tabular}

\begin{tabular}{l|l}
\hline Program Title & What's Happening \\
\hline Date(s) & 10/01/74 \\
& $\begin{array}{l}\text { Methadone: An American Way of Dealing (Julia Reichert \& James Klein, } \\
\text { 1974), Cree Hunters of Mistassini (Boyce Richardson, 1974), Nana, Mom, } \\
\text { and Me (Amalie R. Rothschild, 1974), Earth People (James Rich, unclear) }\end{array}$ \\
\hline Films Screened & $\begin{array}{l}\text { Supervised w/ Ted Perry, MoMA -- Weekly series from October to June } \\
\text { that "consists of social documentaties which are, as a rule, not readily } \\
\text { available to the public." }\end{array}$ \\
Notes & Donnell Media Center, 20 W 53rd St, New York, NY \\
Venue & 222
\end{tabular}




\begin{tabular}{l|l}
\hline Program Title & Fourteenth Century Travel \\
\hline Date(s) & $04 / 01 / 78$ \\
\hline Films Screened & $\begin{array}{l}\text { The Pilgrimage Route to Compostela [Camino de Santiago] (Aritistic } \\
\text { Productions, 1972) }\end{array}$ \\
\hline $\begin{array}{l}\text { Notes } \\
\text { Venue }\end{array}$ & $\begin{array}{l}\text { "Film Presentation [...] with commentary by Mr. William Sloan, Librarian } \\
\text { for the N.Y. Public Library \& Editor, Film Library Quarterly" }\end{array}$ \\
\hline Attendance & Verrazzano Institute at Mercy Collection (Lecture Hall), Dobbs Ferry, NY \\
\hline
\end{tabular}




\section{Bibliography}

\section{Published Sources}

Aceto, Vincent. “Opening New Doors to Film Literacy.” Film Library Quarterly, 1, 3, 1968.

Anacona, Victor. "The Doings at Donnell: Collecting Artists' Tapes for Public Use." Videography, October 1977.

Apple Store Preview, “iScanner - PDF Scanner App.” Apple. https://itunes.apple.com/us/app /iscanner-pdf-scanner-app/id1035331258?mt=8 [accessed May 4, 2018].

Boyd, Gordon. "400 at Linton View 'Underground' Films.”

The Schenectady Gazette, March 12, 1968.

Boyle, Deirdre. "Video: What Librarians Do with a Recycle Medium." American Libraries, 7, 9, 1976.

Boyle, Deirdre. "Video Art: Not for Visionaries Only." American Libraries, 8, 6, 1977.

Boyle, Deirdre. "Video in Public Library Service.” Film Library Quarterly, 11, 3, 1978.

Boyle, Deirdre. “A Voyage of Discovery for Librarians.” American Libraries, 8, 11, 1977.

Brown, Mary A. “Teen-Age Videotape Workshop.” Film Library Quarterly, 5, 3, 1972.

Burnside, Mary Wade. "Librarian Promotes Obscure Films." The Charleston Gazette, October 2, 1987.

Cook, David A. Lost Illusions: American Cinema in the Shadow of Watergate and Vietnam, 1970-1979. Berkeley: University of California Press, 2000.

"East Side Documentary Film.” The Villager, November 19, 1959.

“Events.” MediaLog, 4, 11977.

Film Library Information Council, The. “Cinema Canada.” Press release, 1970.

Film Library Information Council, The. "Frame by Frame.” Press release, 1978.

Film Library Information Council, The. "Frame by Frame II.” Press release, 1979.

Film Library Information Council, The. "Video Art as a Library Medium.” Press release, 1977. 
Film Library Information Council, The. "Videography II." Press release, 1972.

“Film Librarians Organize: Might Help U.S. Build Archives.” Variety, May 31, 1967.

Film Library Information Council, "FLIC: The Film Library Information Council." Press release, n.d.

Freedom Forum. "25th Anniversary Season 1967-1968: The 'Underground' Film.” Press release, March 9, 1968.

"Freedom Forum to Show 3 Films Monday." The Schenectady Gazette, March 9, 1968.

Gerard, Lillian. "Your Program and the News Media." Film Library Quarterly, 7, 3/4, 1974.

Horak, Jan-Christopher. "Archiving, Preserving, Screening 16mm."

Cinema Journal, 45, 3, 2006.

Iarusso, Marilyn. "Film Selection and Programming for Children in Public Libraries." Children's Film Programming: A Handbook, New York: Highsmith Press, 1992.

McCarthy, Anna. The Citizen Machine: Governing By Television in 1950s America. New York: New York University Press, 2010.

Mekas, Jonas. “Movie Journal.” The Village Voice, March 16, 1960.

"New Public Film Librarians Organization Established." Public Library Newsreel, n.d.

New York Film/Video Council, The. "What's Happening, Bill Sloan.” Press release, 2000.

New York Public Library, The. "Donnell Library Center." The New York Public Library. https://www.nypl.org/about/locations/donnell [accessed April 14, 2018].

New York Public Library, The. "Reserve Film and Video Collection."

The New York Public Library. www.nypl.org/about/locations/lpa/circulating-collections/ reserve-film [accessed May 20, 2018].

Museum of Modern Art, The. "New Film Department Appointments Announced at Museum of Modern Art," Press release, August 26, 1980.

"The New York Film Library Offers Wide Range of Services." Public Library Newsreel, n.d.

Palmer, Joseph W. “14-'74 Decades of Service.” Film Library Quarterly, 8, 1, 1975.

Porte, Marsha R. “Fundamentals of Evaluation.” Film Library Quarterly, 5, 4, 1972.

Preiss, David. “Art Films: A Fresh Dimension.” American Artist, 33, 7, 1969.

"Premier of Video Autobiography." MediaLog, 2, 6, 1977. 
Rosenberg, Albert J. "The New Film Library Offers Wide Range of Services." Public Library Newsreel, n.d.

Rossi-Snook, Elena. "Continuing Ed: Educational Film Collections in Libraries and Archives." Learning With the Lights Off: Educational Film in the United States. Devin Orergon, Marsha Orergon, and Dan Streible, eds. Oxford: Oxford University Press, 2012.

Rossi-Snook, Elena. "Persistence of Vision: Public Library 16mm Film Collections in America." The Moving Image, 5, 1, 2005.

"Scholar and Screen: Notes on the Motion Picture Collection of the Library of Congress." The Quarterly Journal of the Library of Congress, 21, 4, 1964.

Sheehy, Carolyn A, ed. Managing Performing Arts Collections in Academic and Public Libraries. Westport: Greenwood Press, 1994.

Silverman, S.M. “Man Behind Quiet MOMA Success.” The New York Post, December 30, 1977.

Sloan, William J. "The Donnell Center Film Library Busily Serves New York." Film News, 18, 4, 1961.

Sloan, William J. "Films in the Sixties: The Search for Excellence." Illinois Libraries, February 1966.

Sloan, William J. "Projections 1967-68.” Film Library Quarterly 1, 1, 1967.

Sloan, William J. "Projections: The Avant Garde of Television," Film Library Quarterly 4, 1, 1971.

Sloan, William J. "Projections." Film Library Quarterly 1, 4, 1968.

Sloan, William J. "Projections," Film Library Quarterly 7, 4, 1974.

Sloan, William J. "Projections," Film Library Quarterly 4, 2, 1971.

Sloan, William J. "Projections," Film Library Quarterly 4, 3, 1971.

Sloan, William J. "Projections.” Film Library Quarterly 4, 4, 1971.

Sloan, William J. "Projections.” Film Library Quarterly 5, 3, 1972.

Sloan, William J. “Projections.” Film Library Quarterly 5, 4, 1972.

Sloan, William J. "Projections." Film Library Quarterly 7, 2, 1974.

Sloan, William J. "Projections," Film Library Quarterly 7, 3/4, 1974.

Sloan, William J. "Projections.” Film Library Quarterly 8, 2, 1975. 
Sloan, William J. "Today's Public Libraries Aid Cultural, Educational Development of Community."Film World, 15, 5, 1959.

Society For Cinema and Media Studies, The. "Organizational History."

The Society For Cinema and Media Studies. https://www.cmstudies.org/page/org history [accessed July 21, 2018].

University Film Study Center at Hampshire College. Summer Institute on Film and Photography, June 17 to July 6, 1973. Amherst: Hampshire College, 1973.

Weinberg, Howard. "Letter from the Council President." The New York Film/Video Council Newsletter. New York: The New York Film/Video Council, 2000.

Winsten, Archer. "Rages and Outrages." The New York Post, December 13, 1968.

Zimmerman, Patricia R., and Scott MacDonald. The Flaherty: Decades in the Cause of Independent Cinema. Bloomington: Indiana University Press, 2017.

\section{Unpublished Primary Sources (William J. Sloan Documents)}

Diodati, Carmen. Carmen Diodati to William J. Sloan, April 22, 1977. Letter. From The New York Public Library, William J. Sloan Documents.

“Film Library Organization.” Meeting minutes. New York, NY, May 12, 1967.

Holmgren, Edwin S. Edwin S. Holmgren to William J. Sloan, May 1, 1980. Letter. From The New York Public Library, William J. Sloan Documents.

Iarusso, Marilyn. "Report on a Special Collection: The Film Library." 1972.

Lippman, Monroe. Monroe Lippman to William J. Sloan, May 13, 1968. Letter. From The New York Public Library, William J. Sloan Documents.

Porte, Marsha R. Marsha R. Porte to William J. Sloan, March 23, 1960. Letter. From The New York Public Library, William J. Sloan Documents.

Porte, Marsha R. Marsha R. Porte to ALA Noon-Day Program Committee, April 5, 1960. Letter. From The New York Public Library, William J. Sloan Documents.

Porte, Marsha R. Marsha R. Porte to William J. Sloan, April 5, 1960. Letter. From The New York Public Library, William J. Sloan Documents.

Sloan, William J. "Annual Report for ALA Midwinter: Motion Picture Preview Subcommittee of the Audio-Visual Committee," New York, NY, 1965. 
Sloan, William J. Curriculum Vitae, n.d.

Sloan, William J. “Donnell Film Library Annual Report 1976-1977.” New York, NY, 1977.

Sloan, William J. “Donnell Film Library Annual Report 1977-1978.” New York, NY 1978.

Sloan, William J. "Film and the Library.” (syllabus, Pratt Institute, Brooklyn, NY, 1970).

Sloan, William J. “Film Library: Annual Report 1957-58.” New York, NY, 1958.

Sloan, William J. “Film Library: Annual Report 1964-65,” New York, NY, 1965.

Sloan, William J. “Film Library Annual Report 1969-70.” New York, NY, 1970.

Sloan, William J. "Films: ALA Yearbook.” Report, New York, NY, 1980.

Sloan, William K. "Films and the Public Library: Selection and Programming."

Paper presented at the IFLA/FIAB Conference, Copenhagen, August 1969.

Sloan, William J. "History of Video Service in The New York Public Library, Branch Libraries." Report, April 8, 1977.

Sloan, William J. "Introduction to Film Study: An Examination of the Non-Narrative Film." (syllabus, Hampshire College, Amherst, MA, 1973).

Sloan, William J. "Nonprint Proposals Created by the Nonprint Media Committee." New York, NY, n.d.

Sloan, William J. "Report of Committee Activities, July 1961, to June, 1962." New York, NY, 1962.

Sloan, William J. "Report for ALA Midwinter Conference 1967: Motion Picture Preview Subcommittee of the Audio Visual Committee." New York, NY, December 4, 1966.

Sloan, William J. William J. Sloan to Don Walker, January 3, 1976. Letter. From The New York Public Library, William J. Sloan Documents.

Sloan, William J. William J. Sloan to Edwin Holmgren, April 29, 1977. Letter. From The New York Public Library, William J. Sloan Documents.

Sloan, William J. William J. Sloan to Edwin Holmgren, April 23, 1980. Letter. From The New York Public Library, William J. Sloan Documents.

Sloan, William J. William J. Sloan to Frances Flaherty, December 12, 1971. Letter. From The New York Public Library, William J. Sloan Documents.

Sloan, William J. William J. Sloan to Ted Perry, February 23, 1978. Letter. From The New York Public Library, William J. Sloan Documents. 
Sloan, William J. William J. Sloan to Carmen Diodati, April 27, 1977. Letter. From The New York Public Library, William J. Sloan Documents.

Sloan, William J. William J. Sloan to Masha R. Porte, March 23, 1960. Letter. From The New York Public Library, William J. Sloan Documents.

Sloan, William J. William J. Sloan to Masha R. Porte, April 8, 1960. Letter. From The New York Public Library, William J. Sloan Documents.

Sloan, William J. William J. Sloan to Masha R. Porte, May 4, 1960. Letter. From The New York Public Library, William J. Sloan Documents.

Sloan, William J. William J. Sloan to Michael Ayres, October 26, 1971. Letter. From The New York Public Library, William J. Sloan Documents.

Sloan, William J. William J. Sloan to Ted Perry, February 23, 1978. Letter. From The New York Public Library, William J. Sloan Documents.

Walker, Don. "Speech made by D. Walker - Coordinator of Adult Services at a Going Away Party for Bill Sloan on May 21, 1980.” Speech. May 21, 1980.

\section{Unpublished Primary Sources (General)}

Sloan, Jennifer. “Speaking Notes for Bill Sloan's Memorial.” Speech. Google Doc. October 2017. 